\title{
The Implementation of Learning Organization Elements and Their Impact towards Organizational Performance amongst NPOs in Singapore
}

\author{
Hishamuddin bin Md.Som ${ }^{1}$, Roland Yeow Theng Nam ${ }^{1}$, Sazali Abdul Wahab ${ }^{1}$, Rashid Nordin ${ }^{1} \&$ Azizul Hakim \\ Mashkuri $^{1}$ \\ ${ }^{1}$ Faculty of Defence Management and Studies, National Defence University of Malaysia, Kuala Lumpur, \\ Malaysia \\ Correspondence: Rashid Nordin, Faculty of Defence Management and Studies, National Defence University of \\ Malaysia, Sungai Besi Camp, 57000, Kuala Lumpur, Malaysia. Tel: 60-1-3750-3100. E-mail: \\ rashidnordin19@gmail.com
}

Received: February 23, 2012 Accepted: May 20, 2012 Online Published: June 16, 2012

doi:10.5539/ijbm.v7n12p2

URL: http://dx.doi.org/ijbm.v7n12p2

\begin{abstract}
The purpose of this paper is to investigate how Learning Organization Elements (LOE) was implemented amongst non-profit organizations (NPO's) in Singapore. Through a self-administered survey and in-depth interviews, organizational performances of 60 non-profit organizations NPOs were evaluated, whilst the extent to which the LOE were carried out within these NPOs were also discussed. Findings suggest that elements such as clarity of mission and vision, experimentation and intrinsic motivation, leadership commitment and empowerment, and organizational learning practices were deemed to be essential for NPOs to be transformed into a learning organization. Other elements such as individual learning and team-problem solving as well as organizational learning practices were also mentioned by respondents as important elements toward NPOs' performance. Implications of the study including the applications of those LOE together with a strategic dimension in order for NPOs to become learning organizations, as well as to achieve superior organizational performance were also highlighted.
\end{abstract}

Keywords: organizational learning practices, learning organization, NPO's performance

\section{Introduction}

The concept of learning organization (LO) has been the focus of management theorists and practitioners for both its theoretical development and endeavor at practical implication (Mintzberg et al., 1998). The concept of such organizations became salient because many of them acknowledge that learning provide competitive advantage and effectiveness. The significance of LO derives from the organization's ability to learn more quickly than their competitors, which is considered the only sustainable corporate advantage. Business organizations were called to become $\mathrm{LO}$ as the world moves toward internationalization and entered into the age of globalization where they are needed to remain competitive and relevant. According to Lloyd and Maguire (2002), the focal point for future sustainable organizational success will be on what the organization knows about itself and its environment, and not the transient structure and detailed processes. Organizations, teams and individuals need to engage in a continuous loop of learning to sustain agility and organizational transformation.

LO can then be defined and described in different ways, such as "a learning organization is a consciously managed organization with learning" as a vital component in its values, visions and goals, as well as in its everyday operations and their assessment. The LO eliminates structural obstacles of learning, creates enabling structures and takes care of assessing its learning and development. It invests in leadership to assist individuals in finding the purpose, in eliminating personal obstacles and in facilitating structures for personal learning and getting feedback and benefits from learning outcomes (Moilanen, 1999a). Given the significant benefits of becoming a LO, numerous attempts have been made to define optimal transformation strategies (Dierkes et al., 2000; Child, 2003). Some scholars place emphasis on the learning practices of the organization's members (Entrekin and Court, 2001; Amy, 2008), while others focus on the organization's competitiveness and capabilities in all management functions (Jackson et al., 2003). Particularly, Senge (1990a) adopted a broader approach and assimilated most of the mentioned perspectives by promoting five key disciplines of the LO, which 
include: (i) personal mastery, (ii) mental model, (iii) shared vision, (iv) team learning, and (v) system thinking. Similarly, Gavin and Richards (1997) recommends the acquisition of skills in five main activities: (i) system problem-solving, (ii) experimentation, (iii) learning from histories, (iv) learning from best practices, and (v) efficient knowledge transfer.

While attentions to become LO have widely provided for the commercial/ business organizations, there are very limited studies done on non-profit organizations (NPOs) and how they could also benefit from such an important process of organizational development. As NPOs are similarly subjected to continuous change and expected to deliver continuous improvement in their standards, effectiveness of programmes and service delivery, the LO concept is therefore an appropriate foil for this study of NPOs. The essential focus of the study was to investigate the developmental process of LO and its relevant practices amongst the human social service NPOs in Singapore. Specifically, the study described the elements that were most important for NPOs to be transformed into LOs were ascertained. The contribution of the study lies on the aspects of the practices and development of non-profit LO, and function toward NPO's performance. Implications for organizational development and management within human social service NPOs in Singapore were derived from this study, whilst some recommendations for managers of NPOs were also included.

\section{Literature Review}

While the importance of becoming a LO is widely discussed and its organizational forms have been studied from various standpoints, ambiguity remains in the use of the terms "organizational learning" and "learning organization". Various scholars assumed the two concepts to be inter-related and can therefore be used interchangeably (Ortenblad, 2001), while others argue that such assumptions have generated confusion of two similar but still different concepts (Tsang, 1997; Easterby-Smith et al., 2001; Friedman et al., 2005). According to Petra et al. (2002), part of this disorganization is due to the scarcity of empirical studies in the subjects, as a means to test learning models, theories, and concepts for their validity, usefulness, and practical value. Specifically, Tsang (1997) mentioned that organizational learning (OL) is a relatively descriptive approach of organizational development strategy, while LO focuses on a prescriptive approach of learning practices within organizations. Based on Tsang's explanation, OL focuses on "how does an organization learn?" whereas LO is concerned with the question of "how should an organization learn?" These understandings were largely agreed upon by various scholars who cited OL as a concept to describe certain types of learning activities that take place in an organization, while LO referred to a particular type of organization in and of itself (Barnard, 2004; Jensen and Rasmussen, 2004; Yeo, 2005). In particular, Tsang (1997) defines OL as learning practices that promote change by shifting the relationship between thoughts, organizational actions and environmental responses. The emphasis of this definition lies on the types of learning practices in promoting change, which in turn define OL as practices for successful organizational transformation.

With respects to the definitions of LO, Senge (1990a) defines it as one where "people continually expand their capacity to create the results they truly desire, where new and expensive patterns of thinking are nurtured, where collective aspiration is set free and where people are continually learning how to learn together" (p. 3). There is a strong humanistic perspective where people are the key element towards the development of a LO, and it must also involve creative thinking and collective learning practices. Other relevant definitions from the literature describe the LO as an ideal organization form that has a system of learning to reach its strategic goals, which include enhancement of organizational performance or acquiring of organizational competitiveness (Whittington, 2003; Jensen and Rasmussen, 2004; Jarzabkowski, 2005). Table 1 presents a summary of definitions of a LO.

Table 1. Summary of definitions of learning organization

\begin{tabular}{lll}
\hline \multicolumn{1}{c}{ Author } & Year & Definition \\
Senge & $1990 \mathrm{a}$ & $\begin{array}{l}\text { Where people continually expand their capacity to create the } \\
\text { results they truly desire, where new and expensive patterns of } \\
\text { thinking are nurtured, where collective aspiration is set free, and } \\
\text { where people are continually learning how to learn together. }\end{array}$ \\
Pedlar et al. & 1991 & $\begin{array}{l}\text { Learning organization is a learning company that facilitates the } \\
\text { learning of all its organizational members and continuously } \\
\text { transforms itself to meet its strategic goals. }\end{array}$ \\
& 1992 & $\begin{array}{l}\text { Learning organization is a firm with the organizational system and } \\
\text { Structure that facilitates a large body of committed and aligned } \\
\text { individuals in spontaneous learning. }\end{array}$ \\
\hline
\end{tabular}




\begin{tabular}{|c|c|c|}
\hline Pearn et al. & 1995 & $\begin{array}{l}\text { Learning organization can be applied to any group of people who } \\
\text { need and desire to improve performance through learning. }\end{array}$ \\
\hline Gephart et al. & 1996 & $\begin{array}{l}\text { A learning organization has an enhanced capacity to learn, adapt } \\
\text { and change. It is an organization in which learning processes are } \\
\text { analyzed, monitored, developed, managed and aligned with } \\
\text { improvement and innovation goals. }\end{array}$ \\
\hline Marsick and Watkins & 1997 & $\begin{array}{l}\text { Learning organization is one that creates intentional processes or } \\
\text { system that accelerates the creation and utilisation of knowledge } \\
\text { across the organizational functions. }\end{array}$ \\
\hline Easterby-Smith & 1997 & $\begin{array}{l}\text { It is an ideal state in a change-oriented enterprise where learning is } \\
\text { maximized. }\end{array}$ \\
\hline Skyrme & 2003 & $\begin{array}{l}\text { A learning organization is one that has in place systems, } \\
\text { mechanisms and processes that are used to continually enhance its } \\
\text { capabilities and those who work with it or for it, to achieve } \\
\text { sustainable objectives - for itself and the communities in which it } \\
\text { participates. }\end{array}$ \\
\hline Armstrong and Foley & 2003 & $\begin{array}{l}\text { A learning organization has appropriate cultural facets (visions, } \\
\text { values, assumptions and behaviors) that support a learning } \\
\text { environment; processes that foster people's learning and } \\
\text { development by identifying their learning needs and facilitating } \\
\text { learning; and structural facets that enable learning activities to be } \\
\text { supported and implemented in the workplace. }\end{array}$ \\
\hline Moilanen & 2005 & $\begin{array}{l}\text { A learning organization is a consciously managed organization with } \\
\text { learning as a vital component in its values, visions and goals as well } \\
\text { as in its everyday operations and their assessment. }\end{array}$ \\
\hline
\end{tabular}

A comprehensive literature review conducted by Ortenbald (2001) noted three normative distinctions between $\mathrm{OL}$ and the LO. First, OL is viewed as a process or set of organizational attributes that differs from that of traditional organizations, whereas the LO is seen as a form of transformed organization (Tsang, 1997). Second, OL takes place naturally in organizations, whereas strategic efforts are required to develop a LO (Crossan and Berdrow, 2003; Jensen and Rasmussen, 2004; Beer et al., 2005). Third, OL emerged from academic inquiry and research, while the existing literature of LO evolves from theories of organizational development (Easterby-Smith, 1997; Easterby-Smith et al., 2001; Jensen and Rasmussen, 2004; Dymock and McCarthy, 2006).

On this aspect, Ortenbald (2001) subsequently concluded his findings by suggesting two main distinctions: (i) OL focuses on people who practice learning in the organization, while (ii) a LO is structured with a focus on determining where knowledge should be gathered and shared within the organization and is a place where organizational setting, culture, systems and practices must be designed and enforced. If an organization wants to become a LO, it is the implementation of OL that is the core of its development (Tsang, 1997; Huysman, 2001; Sun and Scott, 2003; Barnard, 2004). This idea is supported by Finger and Burgin (1999) who regard the LO as an ideal organization form while OL includes activities and processes of learning, by which the organization strives to reach this ideal organizational setting. The two are not mutually exclusive; an organization becomes a LO through the processes of OL (Murray and Donegan, 2003; Murray and Moses, 2005; Yang, 2007). Thus, in order for an organization to be considered a LO, it must possess the key attributes of OL with the appropriate organizational culture, structure and system. This was affirmed by Slater and Narver (1995) and Murray and Donegan (2003) that OL processes help people discover why problems are seen in a one-dimensional framework, posing questions about the current systems, while challenging and questioning paradoxes as they occur. Such learning institutionalises a sense of creativity and improvement within the organization, resulting in a LO that is quick in reconfiguring its architecture and reallocating its resources to focus on emergent opportunities and performance enhancement. The theoretical dimension of the LO was further discussed by Easterby-Smith et al. (1998) who stated that "the LO literature is not devoid of theory; it draws very heavily from ideas developed within OL but it is selective on the ground of utility" (p.8). This view is corroborated by Argyris and Schön (1996) as they advocate that LO literature offer "prescriptions that are useful at least as guides to the kinds of organizational structures, processes and conditions that may function as enablers of learning" (p. 6). 
Based on the above discussions, it is fairly clear that an NPO must possess certain OL attributes to be considered a LO. Any attempt to construct a LO that does not take OL into consideration will likely be found wanting. The aforementioned literature suggested two corollaries that would function as assumptions in this thesis. Firstly, an NPO, like any other organization, has the capability to implement OL. The primary consensus in the relevant literature is that all organizations have the capability to learn, as organizational members have the capability to pursue active learning and knowledge acquisition in order to perform their work effectively. Accordingly, this study explores learning at all organizational levels. Secondly, as becoming a LO relies on a systemic approach; other elements which include knowledge acquisition, dissemination and utilisation should also be present in a LO. As a whole, the creation of a LO should be pursued from the strategic perspective of organizational development. Table 2 presents a summary of concepts and their differences. As the concept of the LO is widely discussed, researchers have also suggested strategies and complex frameworks in order to transform contemporary organizations into LOs.

Table 2. Emphasis of organizational learning and learning organization

\begin{tabular}{lll}
\hline $\begin{array}{l}\text { Emphasis } \\
\text { Fundamental Concept } \\
\text { Research Focus }\end{array}$ & \multicolumn{1}{c}{$\begin{array}{c}\text { Organizational Learning } \\
\text { Academic and theoretical inquiry } \\
\text { Concentrates on processes and } \\
\text { practices of learning within the } \\
\text { organization }\end{array}$} & $\begin{array}{l}\text { Learning Organization } \\
\text { Organizational development purposes } \\
\text { Concentrates on prescriptions and } \\
\text { developmental strategies, systems and } \\
\text { culture in the organizational context } \\
\text { Emphasises total organizational }\end{array}$ \\
& $\begin{array}{l}\text { Segmented into individual, team } \\
\text { and organizational levels, } \\
\text { commonly known as attributes of } \\
\text { organizational learning }\end{array}$ & $\begin{array}{l}\text { involvement including leadership, } \\
\text { cultural development, reward systems } \\
\text { and learning of best practices that would } \\
\text { impact organizational performance } \\
\text { Structure- and strategy- oriented }\end{array}$ \\
\hline
\end{tabular}

As LO is being developed through a comprehensive implementation of OL, two distinctive frameworks of LO with relevant elements were identified in this study and utilized to evaluate the current status of LO development amongst NPOs in Singapore. Essentially, the Learning Organization Action Imperatives discovered by Watkins and Marsick (1997) focuses on four distinctive levels of learning: (i) individual, (ii) team, (iii) organization, (iv) society, and seven elements on which the design of a LO depends. These are: (i) create continuous learning opportunities, (ii) promote inquiry and dialogue, (iii) encourage collaboration and team learning, (iv) establish systems to capture and share learning, (v) empower people towards a collective vision, (vi) connect the organization to its environment, and (vii) provide strategic leadership for learning. The framework can be considered a practical developed model that has the advantage of bringing together very distinct organizational components to build a LO. In reference to the earlier discussion on $\mathrm{OL}$ as processes or practices towards building a LO, the model has incorporated the three fundamental OL attributes, which include individual, team and the organization. Furthermore, the model comes with a survey instrument: The Dimensions of the Learning Organization Questionnaire (DLOQ) to assess the extent to which organizations embody these attributes. Essentially, this model is relevant to the non-profit sector for three specific reasons. First, it connects the NPO to its environment by involving learning at the societal level. This concept is in line with the strategic planning process where external environmental scanning is required for an organization to effectively predict future changes and anticipate trends (Jain, 1984; Costa et al., 1997; Eisenhardt and Martin, 2002). Research shows that the degree of importance attached to environmental scanning can be inferred from the way scanning and learning activities are integrated into the overall organizational strategic planning purposes (Fahey and King, 1981).

As the aforementioned review pointed out that OL take place through individual and team learning. After all, organizations cannot learn like individuals but instead depend on people to carry out strategic learning practices. The contention is that $\mathrm{OL}$ is related to the experiences and actions of its members and the utilisation of collective knowledge. OL can be identified "by studying the concrete structural and procedural arrangements through which actions by members that are understood to entail learning are followed by observable changes in the organization's pattern of activities" (Cook and Yanow, 1993, p. 375). OL then becomes the foundation of LO, which includes the cultures, strategies and procedures that allow the organization and its members to learn 
(Ahmed et al., 2002; Watson, 2005; Woodbury, 2006).

While this study asserts OL as a fundamental element towards the successful development of LO, as any organization may learn on some scale, what is unique about a true LO is the existence of ideologies, systems and structures that not only facilitate individual and team learning, but push the organization to go beyond its current understanding of what works today by continually scanning, assessing and questioning its current standing. Organizations with these characteristics are willing and able to continually question their existing dominant logic and change these views, beliefs, process and approaches, if required, and embrace and act upon new knowledge from the strategic dimension (Prahald and Bettis, 1986; Senge, 1990b). A LO can therefore be viewed as an entity that purposefully adopts organizational cultures and strategies to encourage OL (Ortenbald, 2001; Jensen and Rasmussen, 2004; Graham and Nafukho, 2007).

The second LO framework identified in this study addresses the cultural and strategic LOE is the five strategic building blocks (Goh and Richards, 1997), which include: (i) clarity of organizational mission and vision, (ii) leadership commitment and empowerment, (iii) experimentation and rewards, (iv) effective transfer of knowledge, and (v) team problem-solving. The scholars further recommended two major supporting foundations necessary for the five strategic building blocks: (i) an effective organizational design that is aligned with and supports the building blocks, and (ii) appropriate employee skills and competencies needed for the tasks and roles described in the strategic building blocks. In summary, organizations that possess most of these characteristics are classified as those with a high level of OL and the capacity to become LOs. Furthermore, the five strategic building blocks of LO are relevant to helping organizations in the non-profit sector clarify their missions and visions. This is essential as many NPOs are formed with a clear intention to serve their communities, while organizational member's understanding and commitment to the mission and vision are commonly the determinants of organizational success (Rose, 1996; Hamel, 1997). The model also spells out the importance of leadership and management involvement in building a LO. Specifically, the leadership it advocates is the type that leads through role models, personal influence and passion. Most importantly, when compared with Watkins and Marsick's model (1997), the five strategic building blocks comprise essential organizational factors that facilitate the specific learning culture through mission and vision clarification, strategic emphasis of work experimentation and a reward system (motivation) and effective transfer of knowledge. As a whole, the OL attributes and strategic building blocks of LO have been classified as the Learning Organization elements (LOE) in this study.

\section{Performance Measures of Non-Profit Organizations in Singapore}

Performance measurements of NPOs are largely different from the commercial organizations. The former has little or no profit maximising focus, low potential for income generation and, generally speaking, no bottom line against which performance can ultimately be measured in the financial terms. The vast majority of NPOs still generate most of their income from the government or the general public (Boland and Fowler, 2000). Similarly, Drucker (1990) believes that the single greatest difference between NPOs and government and private organizations is the source of money. Business raises money from customers and government from taxes, but the NPOs receives their main source of income from donors: the money is not their own, but held in trust for the donors. This implied that the goals of NPOs are not to provide profit for their stakeholders, rather to use the donated funds to benefit the intended clients or communities for which these NPOs set to accomplish. Very often the decisions made by the management of a NPO were intended to generate welfare and changing the conditions of lives for their clients or beneficiaries. Consequently, organization's performance is determined by how the NPOs organise and execute their programmes and services (Pfeffer, 1982; Shim and Siegel, 1997).

With the aim to discover appropriate performance measures of NPOs, Durtina (1984) suggested two key performance indicators for that purpose, which includes: (i) service and programme's effectiveness, which focuses on the degree to which the programme or service is achieving its intended public purpose, and (ii) organizational efficiency or management's use of resources to achieve programme or service results. Pappas (1996) mentioned that NPOs' performance measures should include indicators on the improvement of the clients' quality of life. This measure refers to the "overall performance of NPOs in delivering high level of quality services (p. 172). Commonly referred to as the results, impact, or achievements of the NPO with the following three measures: (i) mission performance - the delivery of mission-based programmes and services with tangible, positive outcomes for service users or clients, (ii) knowledge performance - the ability and capability to act on what has been learned in the organization, resulting in continuous improvement and innovation, both internally and in the larger non-profit sector, (iii) financial performance - broad-based financial measures that capture both current and long-term operating perspectives in the non-profit sector that are appropriate for internal management needs as well as external constituents and accrediting, certifying agencies. Similar performance 
indicators were also mentioned by Nathan (1998), which includes: (i) superior programme and service's quality, (ii) increase in clients or membership, and (iii) increase in funding and larger endowment. With reference to the performance indicators recommended by various literatures, the current research proposed four financial performance indicators: (i) collection of funds and donations, (ii) funds usage on direct charitable programmes and services, (iii) operating and administrative expenses, and (iv) annual reserve.

Apart from the financial measures, five non-financial performance indicators were also included in evaluating effects and impacts of human social service NPOs in Singapore. These indicators include: (i) clients' satisfaction on programmes or services (Palntz et. al., 1997; Paton and Foot, 1997; Nathan, 1998; Elaine et. al., 2001), (ii) programme and service's efficiency (Yoder and Ferris, 1997; Nathan, 1998; Elaine et. al., 2001), (iii) increase in clients, (iv) programme and service's quality (Kanter and Summer, 1987; Pappas, 1996; Palntz et. al., 1997), and (v) overall programme and service's effectiveness and implementation, where evaluation of impact is taken into close consideration (Durtina, 1984; Pappas, 1996). The combination of both financial and non-financial performance indicators provided a holistic approach in evaluating the overall performance of NPOs.

Essentially, clients' satisfaction evaluates the satisfactory level of clients upon participating in the programmes and services of NPOs (Paton and Foot, 1997; Nathan, 1998; Elaine et al., 2001; Gainer and Padanyi; 2004). In order to remain relevant to the community in this era of constant change, NPOs are required to "deliver tailored and high-quality programmes and services that fulfil the needs of the clients" (Emanuele, 2004, p. 16). Various scholars have also indicated that in order to obtain clients' satisfaction, the NPOs must develop and deliver programmes and services that fulfil their immediate needs (Stevenson et al., 2002; Vazquez et al., 2002). Programme and service's_efficiency as the second non-financial performance indicators aims to determine the amount of time needed for programmes and services to be developed and delivered to the intended clients. As mentioned by Posavac and Carey (2002), the efficiency of NPOs depend on how fast they respond to clients' needs, and develop relevant programmes and services in meeting those identified needs. From the performance evaluation perspective, NPOs that are efficient in generating programmes and services for arising community or social needs can be considered as one that is needs responsive, which is important towards sustaining clients and acquiring of financial supports (2001; Bamberger et al., 2004). Thirdly, programme and service's quality determines the quality of a programme or service (Paton and Foot, 1997; Brudney and Gloec, 1997; Nathan, 1998; Werther and Berman, 2001; Erik, 2006). The proposed performance indicators do not limit on a specific service standard but allow individual NPOs to determine their perceived level of performance and quality standards. This idea coincides with the principle of outcome evaluation of NPOs as they should indicate its predicted outcomes rather than setting performance yardsticks that are irrelevant to the programmes and services objectives (Kettner and Martin, 1996; Werther and Berman, 2001; Jansen, 2004). Apart from the mentioned indicators, the increase in the number of clients and membership indicates the relevance of programmes and services (Plantz, et al., 1997; Gainer and Padanyi, 2004). Conversely, a declining in number of clients reflects the end of a programme and service life cycle, which in turn questions the relevance of the NPOs. Parallel to Posavac and Carey's (2002) performance measurement criterion, needs analysis should be performed prior to any programme and service development. This process includes the analysis of the clients' population that may require a particular programme, service or intervention. Lastly, NPOs should also be evaluated on their overall programme and service's effectiveness and implementation (Paton and Foot, 1997; Fine et al., 2000; Kaplan, 2001; Elaine et al., 2001), which includes determining the extent of positive changes and the impact of NPO's programmes and services on their clients and the progress toward achieving the broader societal objectives (Joyce, 1999; Fine et al., 2000; Mattessich, 2003; Fitzpatrick et al., 2004). As mentioned by numerous scholars, NPOs need to constantly enhance the effects and quality of their programmes and services through regular evaluations in order to meet the social and community needs (Billis and Glennerster, 1998; Stevenson et al., 2002; Vazquez et al., 2002). It can then also be considered as a quality assurance indicator to ensure that resources are allocated to achieve the mission of the NPO (Paton and Foot, 1997; Werther and Berman, 2001; Zahra and George, 2002; Baldwin and Danielson, 2002; Goh and Ryan, 2002).

\section{Research Methodology}

In line with what is described above, this paper adopts the frameworks of LO by Watkins and Marsick (1997) and Goh and Richards (1997) respectively. Their relevant surveys of DLOQ (Watkins and Marsick, 1997) and Learning Organization Survey (LOS) (Goh and Richards, 1997) were also adopted to gauge progress towards LO in the non-profit human social sector of Singapore.

Specifically, the original DLOQ consisted of 55-items. Several earlier studies conducted by the use of this instrument have also established a high-level reliability and predictive validity (Watkins, Yang and Marsick, 1997, 1998; Yang et al., 2004). Specifically, a research related to business organizational performance indicated 
that the DLOQ has a Cronbach's $\alpha$ coefficient scale ranging from 0.77 to 0.82 , and the reliability estimated for the entire scale of 0.95 (Watkins, Yang and Marsick, 1997). In addition, reliability was obtained from the best model-data fit among alternative measurement models, nomological network among the instrument elements and business organizational performance with the coefficient $\alpha$ ranging from 0.75 to 0.85 (Yang, Watkins and Marsick, 1998). In another study conducted by Selden (1998) on family business using the DLOQ has also obtained high coefficient $\alpha$ ranging from 0.68 to 0.84 . These findings indicated that overall, the DLOQ had acceptable reliability in the aforementioned studies. As the DLOQ was not originally designed for usage in the non-profit sector, constructive adaptation must be done on the survey instrument in order for it to be used in this study. This adaptation includes rephrasing of terms that are not commonly used by the human social service NPOs. In particular, the term "client" is used as to replace the term "customer" in the original survey questionnaires. This is because the term "clients" is most commonly used in the human social service NPOs, as they represent the types of people to be engaged in the programmes and services of NPO (Lyons, 2001; Brown and Kalegaonkar, 2002). In addition, the term "new product" found on the original questionnaire was also rephrased to "new programmes and services", which are more relevant to the non-profit sector.

With regard to the LOS, the original instrument consists of 21 -items. Previous research with the use of the original instrument has established a reliability of Cronbach's $\alpha=0.94$ through a survey with 100 managers from the public sector (Goh and Richards, 1997). In order to adapt the LOS for use in this study, 18-items derived from exhaustive literature review were added. A total of 39-items questionnaire formed the final version of the modified LOS.

These instruments were also designed in order to evaluate the performance of NPOs. Through a comprehensive literature review of NPO's performance, it was recommended that the dependent variables be inclusive of both financial and non-financial performance indicators. Specifically, a total of 19-items were developed, in which 4-items were financial performance related and 15-items were non-financial performance related.

The target population of this study focused on four major groups of human social service NPOs in Singapore, which include: (i) children, youths and family services, (ii) elderly services, (iii) disability services, and (iv) community health services. According to NCSS, the Community Chest (the fund-raising unit of NCSS) raises more than S\$42 million each year in order to support the operations and activities of the various NPOs (NCSS, 2005). As part of the overall plan to enhance programme and service's quality and delivery, the Community Chest intends to raise at least $\mathrm{S} \$ 45$ million each year to support another 10,000 new clients over the existing 354,600 clientele. The latest annual report published by NCSS stated a disbursement of S\$51.7 million across various programmes and services with more than 312,000 clients served (NCSS, 2009).

On the other hand, NPOs that are not funded by the Community Chest would need to raise their own funds accordingly, which makes the total amount of charity funds needed by the whole non-profit sector very much higher than expected. With the largest amounts of financial resources needed and clientele to be served, human social service NPOs were most suitable for the research as they were likely to represent the existing trend of non-profit services in Singapore. Furthermore, due to the diversity of NPOs in Singapore, the decision made to focus on one type of NPOs mainly was to ensure proper selection and construct of performance indicators on the survey instrument. According to Anthony and Herzlinger (1975) and Flynn (1985), performance measurement should identify organizations from the same sector in order for their performance to be accurately compared and analysed. Another advantage of choosing research targets in a single industry is to minimize significant sample heterogeneity and demographic biases (Chryssochoidis and Wong, 2000).

The sampling frame used in this study was based on the online databases of National Volunteers and Philanthropy Centre (NVPC) and National Council of Social Services (NCSS). These databases were administered by the two mentioned organizations, which provide the consolidated information of all NPOs in the nation. Through the search of online databases, a total of 168 human social service NPOs (150 of them are also the members of the National Council of Social Services) were identified. Information of these NPOs with regards to their respective missions, programmes and services, manpower details, types of clientele and annual financial statements can also be obtained from the databases, which were classified as useful information in this study.

Three criteria were then used to guide the sampling procedures in order to identify the NPOs relevant for this study. First, they must be a registered human social service NPO and a member of NCSS. This is to ensure that the NPOs identified for this study abide to the corporate governance and standards of NCSS. Second, the NPO must have been in operation for a minimum of 5 years. This is to ensure that the NPOs have sufficient experience in programmes and services organization and implementation, which is important for the purpose of 
performance evaluation. Third, these NPOs must have key performance indicators (KPIs) relevant to this study. This is to ensure that the NPOs are using the appropriate performance indicators that have been specified in this study, as to ensure validity of measure. Out of 150 NPOs, 70 NPOs that fulfilled the above criteria were identified for this study. For the purpose of this study, the executive directors of the 70 NPOs were identified as survey respondents, as they are the key decision-makers in policies setting, programmes execution, performance evaluation and daily running of the NPOs. Most importantly, they have access to the financial information and service standards required in this study. With the help of the comprehensive database provided by NCSS and NVPC, all names of executive directors and NPOs' addresses can be retrieved accordingly.

Apart from the survey questionnaire, personal interviews were also conducted with the executive directors who were also the respondents of the mailed surveys. The interviewees' selections were based on two specific criteria. First, they must have held the position of executive director in the particular NPO for more than 5 years and function as senior managerial personnel in strategic planning and policies setting. This was to ensure that the respondents have acquired sufficient experience and competencies in managing the NPOs. Second, they must have direct involvement in the NPOs' performance measurement. This was to ensure that the respondents have the capability to provide detailed explanations on how and why the LOE can influence the performance of NPOs. Through a series of phone and/ or face-to-face invitations, eleven executive directors (respondents of the mailed surveys) have agreed to participate as the respondents for the personal interviews. Among the eleven respondents interviewed, five of them were from the children, youths and family service sector, and two respondents from each of the other human social service NPOs that provide disability care, elderly care and community healthcare services. In line with the number of human social service NPOs in Singapore, the children, youths and family service sector forms the largest number of human social service NPOs in Singapore (NCSS, 2005, 2007). Therefore the selection of respondents and the findings generated through the personal interviews were able to provide a wider scope of representation across the non-profit human social service sector of Singapore.

\section{Findings of Descriptive Data}

A total of 60 NPOs responded to the surveys. The demographics of the surveyed NPOs are presented in Table 3. Specifically, 49 respondents $(82 \%)$ indicated that they have been in their current position for more than 3 years, while the average number of years of the respondents' service in the NPO stands at approximately 3.6 years. Majority of the respondents indicated that they have taken a vertical step up the organization's hierarchy by serving as assistant directors or in similar capacities in the current or other NPOs. This implies that the respondents would have acquired sufficient experiences with regards to the NPOs' operations and practices needed for this study.

Table 3. Demographics of the surveyed NPOs

\begin{tabular}{lcc}
\hline Variables & Frequency & Percentage (\%) \\
\hline Years of service with NPOs & 11 & 18 \\
Less than 1 year & 29 & 49 \\
2 to 5 years & 16 & 27 \\
6 to 10 years & 2 & 3 \\
11 to 15 years & 2 & 3 \\
15 years \& above & & \\
Number of full-time staff & 5 & 8 \\
Less than 5 staff & 9 & 15 \\
5 to 10 staff & 4 & 7 \\
11 to 15 staff & 5 & 8 \\
16 to 20 staff & 37 & 62 \\
21 staff \& above & & \\
Number of volunteers & 9 & 15 \\
Less than 5 volunteers & 3 & 5 \\
5 to 10 volunteers & 1 & 2 \\
11 to 15 volunteers & 1 & 2 \\
16 to 20 volunteers & 46 & 76 \\
21 volunteers \& above & & \\
\hline
\end{tabular}


With respects to human resources, 37 NPOs (62\%) have more than 21 full-time employees. Although there are no available indicators to determine how many full-time staff is considered an appropriate staff ratio for these NPOs, the assumption is that the more programmes and services that the NPO organises, the more full-time employees it would require (Michael, 2002; Robert, 2006). Apart from full-time employment, volunteers are also an essential human resource for many of these NPOs. Specifically, $76 \%$ of the NPOs have more than 21 volunteers.

While the literature has indicated the importance of volunteers in NPOs' human resource management (Michael, 2002, Lynn et al., 2006), especially in the area of manpower cost control (Michael, 2002; CCOG, 2006), a research conducted by the Singapore National Volunteers and Philanthropy Centre (NVPC, 2004), reported a shortfall of $30 \%$ in new volunteers recruitment. This shortfall of volunteers was due to the strong competition for available volunteers among the various NPOs. In order to overcome the continuous declining rate of volunteers, the NVPC has indicated the need for NPOs to sustain volunteers' interest, orientate their volunteers to the NPO's mission and vision, as well as to develop effective motivational programmes and/or strategies in order to retain their existing volunteers.

\section{Performance of Npos - Based on Financial Performance Indicators}

As shown in Table 4, there were generally seven major funding sources for these NPOs, which include: (i) community chest (funds administered by NCSS), (ii) government grants (e.g., MCYS, MOE, and MOH etc), (iii) corporate donations, (iv) public donations, (v) charity events and projects, (vi) social enterprises or businesses, and (vii) others. Among the 60 NPOs surveyed, 25 NPOs (42\%) receive their major financial support through government grants, which often require them to present the programme and service's objectives, implementation procedures, significance of activities, as well as measurable outcomes and KPIs in their funding proposals (Chang and Tuckman, 1991; Bryson, 1995).

Table 4. Types of major funding and disbursement

\begin{tabular}{lcc}
\hline \multicolumn{1}{c}{ Variables } & Frequency & Percentage (\%) \\
\hline Types of funding collection & 25 & 42 \\
Government grants & 2 & 3 \\
Community chest & 3 & 5 \\
Social enterprises and businesses & 2 & 3 \\
Charity events & 16 & 27 \\
Public donations & 6 & 10 \\
Corporate donations & 6 & 10 \\
Others & & \\
Funds disbursement & 2 & 3 \\
New programmes and services & 6 & 10 \\
Corporate expenses & 51 & 85 \\
Existing programmes and services & 1 & 2 \\
Reserves & & \\
\hline
\end{tabular}

Table 5. Financial performance of NPOs

\begin{tabular}{|c|c|c|c|c|}
\hline \multirow[b]{2}{*}{$\begin{array}{c}\text { Financial Performance } \\
\text { Indicators }\end{array}$} & \multicolumn{4}{|c|}{ Responses } \\
\hline & $\begin{array}{l}\text { Reduced in Funds } \\
\text { and Donations }\end{array}$ & $\begin{array}{c}\text { Minor Growth } \\
(0.1 \%-5 \%)\end{array}$ & $\begin{array}{l}\text { Medium Growth } \\
(5.1 \%-10 \%)\end{array}$ & $\begin{array}{l}\text { Major Growth } \\
\text { (10.1\% \& above) }\end{array}$ \\
\hline \multirow{2}{*}{$\begin{array}{l}\text { 1. Yearly collection of } \\
\text { charity funds and } \\
\text { donations }\end{array}$} & 13 NPOs & 9 NPOs & 8 NPOs & $30 \mathrm{NPOs}$ \\
\hline & $23.2 \%$ & $16.1 \%$ & $14.3 \%$ & $46.4 \%$ \\
\hline \multirow{2}{*}{$\begin{array}{l}\text { 2. Yearly funds usage } \\
\text { on direct charitable } \\
\text { programmes and services }\end{array}$} & 6 NPOs & 19 NPOs & 6 NPOs & $29 \mathrm{NPOs}$ \\
\hline & $10.7 \%$ & $33.9 \%$ & $10.7 \%$ & $44.6 \%$ \\
\hline
\end{tabular}




\begin{tabular}{l}
\hline 3. Yearly annual \\
reserves of NPO \\
4. Yearly operating and \\
administrative expenses \\
of NPO
\end{tabular}

21 NPOs

$37.5 \%$

Increased in

Operating and

Administrative

Expenses

2 NPOs

$3.5 \%$

Minor Reduction

(0.1\% - 5\%)

29 NPOs

$44.6 \%$
6 NPOs

$10.7 \%$
0 NPOs

$0 \%$

Medium

Reduction $(5.1 \%$

- $10 \%)$

6 NPOs

$10.7 \%$
37 NPOs

$58.9 \%$

Major Reduction

$(10.1 \% \&$ above $)$

19 NPOs

$33.9 \%$

As shown in Table 5, there was a positive growth in the collection of funds and donations among the NPOs. Specifically, only 13 NPOs (23\%) encountered a reduction in funds and donations, while 38 NPOs $(60 \%)$ experienced more than $5 \%$ growth in funds and donations in comparison with the previous fiscal year. This implied that the majority of the NPOs were able to solicit substantial amounts of charity funds for their operations and organisation of programmes and services. As indicated by several scholars, a healthy national economy will generate more financial surpluses to support the work of NPOs (Weisbrod and Dominguez, 1986; Ross, 1996; Speckbacher, 2003). During good economy performing years, funds from various sources, including government grants, philanthropy foundations as well as the general public are likely to increase. Conversely, charity funds tend to reduce during economic recessions (Wilhelm and Fiestas, 2005; Rodrik, 2005; Pharoah, 2008).

Based on the annual economic reports of Singapore, the national economy grew by $8.3 \%$ in $2004,6.4 \%$ in 2005 and $7.9 \%$ in 2006. It was further reported that the economy grew by $7.6 \%$ in the third quarter of 2007 (MTI, 2007). These growths indicated strong national economical conditions during the mentioned financial years. Therefore, based on the strong economical condition of Singapore, it was not a surprise to expect higher percentage growth in the collection of charity funds for the NPOs.

In terms of the funds usage on direct charitable programmes and services, 54 NPOs (90\%) encountered positive growth in the use of funds for direct clients' welfare and benefits. Specifically, 19 NPOs (34\%) encountered a minor growth in funds of less than or equal to $5 \%$; 6 NPOs (10.7\%) reported a medium growth in funds between 5.1-10\%; while 29 NPOs (45\%) reported a major growth of more than $10 \%$ in funds usage on direct charitable programmes and services. With respects to annual reserve, 21 NPOs $(37.5 \%)$ encountered a reduction in annual reserves, 2 NPOs (3.5\%) indicated a medium growth of $5.1 \%$ to $10 \%$ in annual reserves, and 37 NPOs (59\%) had an increase in annual reserves above $10 \%$. On the aspect of the operating and administrative expenses, they represent an organization's operational efficiency (Chang and Tuckman, 1991; Stone et al., 1999), and should be closely monitored to ensure operational viability (Plantz et al., 1997; Joyce, 1999; Light, 2000). Specifically, 29 NPOs $(45 \%)$ indicated an increase in these expenses; while 6 NPOs $(10.7 \%)$ reported a reduction in these expenses of less than or equal to $5 \%$, and 25 NPOs (44.6\%) reported a reduction in operating and administrative expenses of more than $5 \%$ in comparison with the previous fiscal year. In summary, more than $80 \%$ of the NPOs utilised their main financial resources for the development and implementation of existing programmes and services. Based on the findings, around $60 \%$ of the NPOs experienced at least $5 \%$ growth in charity funds and donations between the fiscal years of 2007 and 2008. With respects to funds usage on direct charitable programmes and services; $90 \%$ of the NPOs utilised the majority of their funds to generate direct welfare for their intended clients.

With regards to annual reserves, $62 \%$ of the NPOs reported positive annual reserves, which indicated that the NPOs had sufficient funds to develop and deliver programmes as well as services for their clients. On the aspect of operating and administrative expenses, $55 \%$ of the NPOs encountered an overall reduction of corporate expenses ranging from 3\% to $12 \%$ per annum. Based on the findings, majority of the NPOs had utilised their funds for existing programmes and services, whilst operating and administrative expenses of the NPOs were closely monitored and efforts in cost control were also observed.

\section{Performance of Npos - Based on Non-Financial Performance Indicators}

As shown in Table 6, the mean scores for non-financial performance indicators ranged from 3.03 to 3.26. Specifically, a mean score above 3.00 indicated that the NPOs were able to obtain positive non-financial performance outcomes. Based on the findings, more than $90 \%$ of the NPOs were able to generate good clients' satisfaction through their programmes and services, whilst clients' complaints were also managed efficiently and 
effectively. According to Posavac and Carey (2002), being able to fulfil client's needs and achieve programme and service's objectives are the most essential outcomes of successful NPOs. They are required to demonstrate the competencies in generating programmes and services that meet the unique needs of the clients in line with the missions and visions of the NPOs.

The findings also showed that more than $90 \%$ of the NPOs were efficient in generating new programmes and services in respond to new clients' needs, while at the same time delivered the existing programmes and services efficiently. The findings further revealed that the NPOs were able to maintain a high-level programme and service's completion and success rate. Findings as such showed that the NPOs were effective in programmes and services implementation.

In addition, $98 \%$ of the NPOs were able to maintain a high-level programme and service's quality. Essentially, about $90 \%$ of the NPOs used performance criteria to evaluate programme and service's outcome, in order to enhance the quality of their programmes and services. As mentioned by various scholars, programme and service's evaluation is important for the NPOs in determining organizational performance, as well as to generate effective programmes and services in the future (Bozzo, 2000; Feller, 2002; Morley et al., 2002; Fitzpatrick et al., 2004; Rossi et al., 2004).

Table 6. Non-financial performance of NPOs

\begin{tabular}{|c|c|c|c|c|c|c|}
\hline \multirow[t]{3}{*}{ Non-Financial Performance Indicators } & \multicolumn{4}{|c|}{ Responses } & \multirow{3}{*}{ Mean } & \multirow{3}{*}{ S.D } \\
\hline & $1=$ & $2=$ & $3=$ & $4=$ & & \\
\hline & Strongly Disagree & Disagree & Agree & Strongly Agree & & \\
\hline \multicolumn{7}{|l|}{ Clients' Satisfaction } \\
\hline $\begin{array}{l}\text { 1. The NPO is able to generate good } \\
\text { clients' satisfaction through their } \\
\text { programmes and services. }\end{array}$ & $0 \%$ & $3.6 \%$ & $57.1 \%$ & $39.3 \%$ & 3.36 & 0.55 \\
\hline \multirow{2}{*}{$\begin{array}{l}\text { 2. The NPO manages clients' } \\
\text { complaints efficiently and } \\
\text { effectively. }\end{array}$} & $0 \%$ & $5.4 \%$ & $73.2 \%$ & $21.4 \%$ & 3.16 & 0.50 \\
\hline & & & & Mean & 3.26 & 0.53 \\
\hline \multicolumn{7}{|l|}{ Programme and Service's Efficiency } \\
\hline $\begin{array}{l}\text { 1. The NPO invests substantial } \\
\text { amount of money on technology } \\
\text { and computer systems each year. }\end{array}$ & $7.1 \%$ & $46.4 \%$ & $32.1 \%$ & $14.3 \%$ & 2.54 & 0.83 \\
\hline $\begin{array}{l}\text { 2. The NPO is able to generate new } \\
\text { programmes and services } \\
\text { efficiently in response to new } \\
\text { clients' needs. }\end{array}$ & $0 \%$ & $3.6 \%$ & $57.1 \%$ & $39.3 \%$ & 3.27 & 0.65 \\
\hline $\begin{array}{l}\text { 3. Existing programmes and services } \\
\text { are carried out efficiently. }\end{array}$ & $0 \%$ & $7.1 \%$ & $58.9 \%$ & $33.9 \%$ & 3.27 & 0.59 \\
\hline \multirow{2}{*}{$\begin{array}{l}\text { 4. The NPO is able to launch new } \\
\text { programmes and services within a } \\
\text { reasonable timeframe. }\end{array}$} & $0 \%$ & $21.4 \%$ & $53.6 \%$ & $25.0 \%$ & 3.04 & 0.69 \\
\hline & & & & Mean & 3.03 & 0.69 \\
\hline Increase in Clients & & & & & & \\
\hline \multirow{2}{*}{$\begin{array}{l}\text { 1. They are more clients attending the } \\
\text { NPO's programmes and services } \\
\text { each year. }\end{array}$} & $0 \%$ & $7.1 \%$ & $64.3 \%$ & $28.6 \%$ & 3.21 & 0.56 \\
\hline & & & & Mean & 3.21 & 0.56 \\
\hline
\end{tabular}

Furthermore, the findings also showed that staff training has contributed to the enhancement of programme and 
service's quality and the overall organizational effectiveness. There were also more clients attending the NPO's programmes and services each year. However, only $46 \%$ of the NPOs have invested substantial amount of money on technology and computer system each year.

In sum, based on the findings presented, the NPOs were able to generate effective programmes and services that fulfilled the needs of their clients. High-level programme and service's quality were achieved as the NPOs utilised performance criteria to evaluate and improve the quality of their programmes and services. There were also more clients' participation in the NPO's programmes and services, and lastly, programmes and services were generated efficiently in response to new clients' needs.

\section{Learning Organization Elements (LOE) Practiced among NPOs}

As shown in Table 7, the mean scores for the LOE ranged from 3.10 to approximately 3.45 . Specifically, the LOE that was most practiced were in terms of clarity of mission and vision, followed by experimentation and intrinsic motivation, leadership commitment and empowerment, OL practices and team problem-solving.

Table 7. Learning organization elements

\begin{tabular}{clc}
\hline Learning Organization Elements & Mean \\
\hline 1. Individual learning practices & 3.15 \\
2. Team learning practices & 3.16 \\
3. Organizational learning practices & 3.26 \\
4. Clarity of mission and vision & 3.44 \\
5. Leadership commitment and empowerment & 3.27 \\
6. Experimentation and intrinsic motivation & 3.29 \\
7. Effective transfer of knowledge & 3.10 \\
8. Team problem-solving & 3.21 \\
Overall Mean & 3.22 \\
\hline
\end{tabular}

\subsection{Individual Learning Practices}

A LO can be developed when people are constantly encouraged to upgrade their skills, knowledge and expertises. It also needs organizational members to be active inquirers into the organizational norms and practices, so that new ideas and better solutions to problems can be generated. As shown in Table 8 , more than $85 \%$ of the NPOs have organizational members who treat each other with respect, and helping each other to learn and work more effectively. Moreover, it was found in majority of the NPOs that whenever people state their views or ideas, they also ask what others think about the ideas. This signified that people in the NPOs were receptive toward other staff's perspective and ideas, which is an essential element for open communication and knowledge sharing (Robson and Tourish, 2005).

Table 8. Descriptive analysis of individual learning practices

\begin{tabular}{|c|c|c|c|c|c|c|c|}
\hline \multirow{3}{*}{\multicolumn{2}{|c|}{ Individual Learning Practices }} & \multicolumn{4}{|c|}{ Responses } & \multirow{3}{*}{ Mean } & \multirow{3}{*}{ S.D } \\
\hline & & $1=$ & $2=$ & $3=$ & $4=$ & & \\
\hline & & Strongly Disagree & Disagree & Agree & Strongly Agree & & \\
\hline 1. & $\begin{array}{l}\text { Organizational members can } \\
\text { openly discuss mistakes in order } \\
\text { to learn from them. }\end{array}$ & $0 \%$ & $30.4 \%$ & $50.0 \%$ & $19.6 \%$ & 2.89 & 0.71 \\
\hline 2. & $\begin{array}{l}\text { Organizational members are } \\
\text { encouraged to develop the skills } \\
\text { they need for future work tasks. }\end{array}$ & $0 \%$ & $14.3 \%$ & $55.4 \%$ & $30.4 \%$ & 3.16 & 0.65 \\
\hline 3. & $\begin{array}{l}\text { Organizational members get } \\
\text { resources (time, space and } \\
\text { budget) to support their } \\
\text { learning. }\end{array}$ & $0 \%$ & $16.1 \%$ & $51.8 \%$ & $32.1 \%$ & 3.16 & 0.68 \\
\hline
\end{tabular}




\begin{tabular}{|c|c|c|c|c|c|c|c|}
\hline 4. & $\begin{array}{l}\text { Effort in learning is rewarded } \\
\text { monetary. }\end{array}$ & $0 \%$ & $30.4 \%$ & $51.8 \%$ & $17.9 \%$ & 2.88 & 0.69 \\
\hline 5. & $\begin{array}{l}\text { Organizational members are } \\
\text { encouraged to provide open and } \\
\text { honest feedback to each other. }\end{array}$ & $0 \%$ & $21.4 \%$ & $53.6 \%$ & $25.0 \%$ & 3.04 & 0.69 \\
\hline 6. & $\begin{array}{l}\text { Organizational members are } \\
\text { encouraged to ask "why" with } \\
\text { the aim to improve their work } \\
\text { standard and performance. }\end{array}$ & $0 \%$ & $12.5 \%$ & $62.5 \%$ & $25.0 \%$ & 3.13 & 0.60 \\
\hline 7. & $\begin{array}{l}\text { Organizational members spend } \\
\text { time building trust with each } \\
\text { other. }\end{array}$ & $0 \%$ & $10.7 \%$ & $53.6 \%$ & $35.7 \%$ & 3.25 & 0.64 \\
\hline 8. & $\begin{array}{l}\text { Organizational members help } \\
\text { each other to learn to work } \\
\text { better. }\end{array}$ & $0 \%$ & $3.6 \%$ & $58.9 \%$ & $37.5 \%$ & 3.34 & 0.55 \\
\hline 9. & $\begin{array}{l}\text { Organizational members are } \\
\text { given time for learning and } \\
\text { training programmes. }\end{array}$ & $0 \%$ & $14.3 \%$ & $50.0 \%$ & $35.7 \%$ & 3.21 & 0.68 \\
\hline 10. & $\begin{array}{l}\text { Organizational members view } \\
\text { problems as learning } \\
\text { opportunities. }\end{array}$ & $0 \%$ & $17.9 \%$ & $58.9 \%$ & $23.2 \%$ & 3.05 & 0.64 \\
\hline 11. & $\begin{array}{l}\text { People listen to other's point of } \\
\text { view before commenting. }\end{array}$ & $0 \%$ & $14.3 \%$ & $62.5 \%$ & $23.2 \%$ & 3.09 & 0.61 \\
\hline 12. & $\begin{array}{l}\text { Whenever people state their } \\
\text { view, they also ask what others } \\
\text { think. }\end{array}$ & $0 \%$ & $1.8 \%$ & $67.9 \%$ & $30.4 \%$ & 3.29 & 0.49 \\
\hline \multirow[t]{2}{*}{13.} & $\begin{array}{l}\text { Organizational members treat } \\
\text { each other with respect. }\end{array}$ & $0 \%$ & $1.8 \%$ & $53.6 \%$ & $44.6 \%$ & 3.43 & 0.53 \\
\hline & & & & & Overall Mean & 3.15 & 0.63 \\
\hline
\end{tabular}

Based on the findings, people in the NPOs also spend time building trust with each other. According to Jones and George (1998), effective knowledge sharing requires regular communication among organizational members, so that tacit knowledge can be transferred between people. Similar points were also mentioned by other scholars that due to the nature of tacit knowledge, which is highly associated to individual power and personal status can not be easily transferred unless there is a certain level of trust among the organizational members (John, 2003; McEvily et al., 2003; Levin and Cross, 2004).

The findings also revealed that organizational members were given time for learning and to attend training programmes, whilst organizational members were also encouraged to develop the skills they need for future work tasks. In addition, resources such as time, space and budget were also provided to support individual learning practices within the NPOs. These findings showed that the NPOs were supportive of formal learning in order for organizational members to obtain the competencies needed for their jobs. Apart from the aforementioned individual learning practices, it was also indicated that organizational members were encouraged to ask "why" with the aim to improve their work standard and performance. Essentially, this result also signified the implementation of generative learning practices among the NPOs. Based on the findings, monetary reward provided for learning was less practiced in the NPOs.

Through the personal interviews, all 11 respondents stated that individual learning was important to the performance of NPOs, because effective programme and service organization and implementation depend on the professional skills and knowledge of the organizational members. The respondents also mentioned that although personal passion and willingness to serve in the non-profit sectors were important qualities of NPOs' staff; however, many of the jobs and duties require specific skills and know-how.

As illustrated by one of the respondent that:

"We employ professional counsellors and therapists to provide the necessary interventions to our clients...these 
services involve high-level of social intervention skills that required the respective personnel to be properly trained and certified by professional bodies" (Respondent K).

These responses implied the need to acquire organizational members with the specific knowledge and skills that can continue to enhance the quality and delivery of NPO's programmes and services. Findings as such corresponded with the earlier literature of various scholars where individual learning practices are essential for successful organizational development (McDougall and Beattie, 1998, Beeby and Booth, 2000) and superior organizational performance (Kim, 1993; McDougall and Beattie, 1998; Roland 2002; Sabherwal and Becerra, 2003; Amy, 2008).

It was also commented by various respondents that while professional skills and knowledge are highly essential and can affect the effectiveness of the NPO's programmes and services, organizational members also need to have the know-how in programme and service evaluation. As noted by one of the respondent that:

“...through evaluation and tracking of outcomes, future programmes can be organised more effectively..., we should also continuously enhance our knowledge, so that we can deliver high-quality services and generate programmes that will meet the needs of the clients."'(Respondent E).

Other comments mentioned by the respondents with regards to individual learning practices were summarised as follows:

"We can't rely on volunteers to service our clients all the time, although they are useful resources in facilitating some of our programmes and interventions. Nevertheless, the staff must have the relevant skills and knowledge in order to achieve the planned objectives...people must be proactive in learning if they are to be effective in their work." (Respondent A).

"Like any other business organizations, the NPO also needs professional staff in planning and implementing the programmes and services. Hence, we should employ people not just based on passion in voluntary work, but those with professional knowledge in order to provide better care and services to our clients." (Respondent K).

"Individual learning is important for the NPO as clients' needs are so complex and new issues often occur that require our staff to be quick in problem-solving and decision-making. I often encourage the staff to learn from the seniors; or through some form of training programmes that could enhance their skills. Moreover, we can't depend on existing knowledge to service our clients, in fact, the best approach to learn is to review our programmes regularly and have the senior personnel to share their knowledge and insights during evaluations." (Respondent B).

While individual learning has been mentioned as essential practices toward organizational performance, respondents were also asked to clarify: "How is learning facilitated in the NPOs?" All the respondents agreed that organizational members could obtain the necessary skills and knowledge through attending formal learning programmes and organised training workshops. This is because large amounts of training subsidies were provided by the Voluntary Welfare Organizations and Charities Capability Fund (VCF) or Skills Development Funds (SDFs), commonly known as training funds for NPOs and organizations to enhance their employees' skills, corporate services and capabilities. In order to cater to the training needs of the social service sector, the Social Service Training Institute (SSTI) was established in 1990 as the training unit of NCSS to provide relevant training programmes and consultation services to the non-profit sector. The training programmes organised by SSTI focuses on enhancing the quality of the social service workforce as well as to enhance the service standards of both the existing and new NPOs in Singapore.

The School of Non-Profit was subsequently established in 2006 to cater to the uprising demands and professionalism of the social service sector. Apart from the training programmes and consultation services provided by SSTI, other privately-owned training providers are encouraged to develop relevant programmes for their intended audiences with the support of the mentioned funds. Hence, a wide range of skill sets and knowledge are made available through numerous training programmes. Training subsidies from the aforementioned funding sources typically range from $30 \%$ to $95 \%$ of costs per training programme. Thus, many training seminars and workshops with different learning objectives have been organised, and NPOs' managers have made full use of the opportunities to ensure that their staff are sent for appropriate training programmes to upgrade their skills and knowledge. From the human resource development perspective, training enhances the competencies of the individuals.

\subsection{Team Learning Practices}

This element presents teams as the fundamental learning units within a LO. As illustrated in Table 9, more than $85 \%$ of the NPOs have organizational members that treat each other as equals, regardless of rank, culture, or 
other differences. Moreover, while members enjoy being part of the team in handling projects, teamwork has also been the main focus of the NPOs. The aforementioned findings coincided with the literature where the fundamental component for effective team learning and knowledge sharing depend on strong teamwork (Hardaker and Ward, 1987), respect for each other (Jones and George, 1998), as well as seeing oneself as an important member of the team (Linda, 2005). The findings further revealed that organizational members respect the decisions made by the teams, whilst management had confidence in the recommendations provided by the teams. Moreover, teams often revise their decisions through discussions or upon reviewing of new information collected. As part of the team learning practices, organizational members were also given time for learning and knowledge sharing. In addition, teams were allowed the freedom to adapt their goals as needed, whilst opportunity to volunteer their services in new projects were also provided. From the perspective of employee empowerment, Osterloh and Frey (2000) mentioned that organizational members who are constantly encouraged to learning and explore new ideas tend to share what they learn with the other team members. Higher-level of employee's involvement in problem-solving and decision-making can be achieved when the management accepts the recommendations made by the respective teams (Sabherwal and Becerra-Fernandez, 2003; Graham and Nafukho, 2007). It is also important for team member to feel that what they have contributed towards the organization as a whole is appreciated by the management (Edmonson, 1999; Crittenden et al., 2004). Among the various practices, monetary rewards given for team learning were less practiced in the NPOs. This finding was similar to the individual learning practices discussed earlier.

Table 9. Descriptive analysis of team learning practices

\begin{tabular}{|c|c|c|c|c|c|c|}
\hline \multirow[b]{2}{*}{ Team Learning Practices } & \multicolumn{4}{|c|}{ Responses } & \multirow[b]{2}{*}{ Mean } & \multirow[b]{2}{*}{ S.D } \\
\hline & $\begin{array}{c}1= \\
\text { Strongly Disagree }\end{array}$ & $\begin{array}{c}2= \\
\text { Disagree }\end{array}$ & $\begin{array}{c}3= \\
\text { Agree }\end{array}$ & $\begin{array}{c}4= \\
\text { Strongly Agree }\end{array}$ & & \\
\hline $\begin{array}{l}\text { 1. Organizational members treat } \\
\text { each other as equals, regardless } \\
\text { of rank, culture, or other } \\
\text { differences. }\end{array}$ & $0 \%$ & $7.1 \%$ & $50.0 \%$ & $42.9 \%$ & 3.36 & 0.62 \\
\hline $\begin{array}{l}\text { 2. Organizational members focus } \\
\text { on teamwork. }\end{array}$ & $0 \%$ & $14.3 \%$ & $44.6 \%$ & $41.1 \%$ & 3.27 & 0.70 \\
\hline $\begin{array}{l}\text { 3. Monetary rewards are given for } \\
\text { team learning. }\end{array}$ & $3.6 \%$ & $37.5 \%$ & $48.2 \%$ & $10.7 \%$ & 2.66 & 0.72 \\
\hline $\begin{array}{l}\text { 4. Organizational members respect } \\
\text { the decisions made by the teams. }\end{array}$ & $0 \%$ & $3.6 \%$ & $71.4 \%$ & $25.0 \%$ & 3.21 & 0.49 \\
\hline $\begin{array}{l}\text { 5. Organizational members enjoy } \\
\text { being part of the team in } \\
\text { handling projects. }\end{array}$ & $0 \%$ & $8.9 \%$ & $57.1 \%$ & $33.9 \%$ & 3.25 & 0.61 \\
\hline $\begin{array}{l}\text { 6. Teams have the freedom to adapt } \\
\text { their goals as needed. }\end{array}$ & $0 \%$ & $12.5 \%$ & $64.3 \%$ & $23.2 \%$ & 3.11 & 0.59 \\
\hline $\begin{array}{l}\text { 7. Teams often revise their } \\
\text { decisions through discussions or } \\
\text { upon reviewing of new } \\
\text { information collected. }\end{array}$ & $0 \%$ & $7.1 \%$ & $62.5 \%$ & $30.4 \%$ & 3.23 & 0.57 \\
\hline $\begin{array}{l}\text { 8. Management has confidence in } \\
\text { the recommendations provided } \\
\text { by the teams. }\end{array}$ & $0 \%$ & $5.4 \%$ & $67.9 \%$ & $26.8 \%$ & 3.21 & 0.53 \\
\hline $\begin{array}{l}\text { 9. Organizational members } \\
\text { volunteer their services in new } \\
\text { project teams. }\end{array}$ & $0 \%$ & $21.4 \%$ & $57.8 \%$ & $26.8 \%$ & 3.05 & 0.70 \\
\hline $\begin{array}{l}\text { 10. Teams are given time for } \\
\text { learning and knowledge sharing. }\end{array}$ & $0 \%$ & $5.4 \%$ & $66.1 \%$ & $28.6 \%$ & 3.23 & 0.54 \\
\hline
\end{tabular}

\subsection{Organizational Learning Practices}

This element refers to the processes and systems of knowledge acquisition, utilization, and memory (knowledge storage and organization) within a LO. As shown in Table 10, the management was supportive towards learning, 
knowledge acquisition and sharing, whilst managers also ensured that the organizational actions and policies are consistent with its mission and general objectives. These findings coincided with the literature where knowledge sharing and utilization or any form of related developments must fulfill the mission of the organization or for the purpose of organizational advancement (Senge, 1993; Sawhill and Williamson, 2001; Gupta and Michailova, 2004).

Table 10. Descriptive analysis of organizational learning practices

\begin{tabular}{lccccc}
\hline & \multicolumn{4}{c}{ Responses } \\
\cline { 2 - 5 } Organizational Learning Practices & $1=$ & $2=$ & $3=$ & $4=$ & Mean S.D \\
\cline { 2 - 5 } & Strongly Disagree & Disagree & Agree & Strongly Agree \\
\hline
\end{tabular}

\section{Knowledge acquisition}

1. We encourage organizational members to take ownership for resources needed to accomplish their work.

2. We encourage organizational members for taking initiatives in learning and transform their knowledge into reports and computerized documents.

3. We encourage organizational members to learn new skills and knowledge through problem-solving and group discussion.

4. We work closely with both the internal and external counterparts in order to acquire new knowledge.

5. We encourage organizational members to acquire information and knowledge from across the NPO when solving problems.

6. We encourage organizational members to bring the clients' view into the decision-making process.

7. Management is supportive towards learning, knowledge acquisition and sharing.

8. Managers continually look for opportunities to learn.

9. Managers empower organizational members to acquire the skills and knowledge needed to achieve the mission.

\section{Knowledge utilisation}

10. We give assignments based on abilities and skills of organizational members.

11. We engage organizational members' skills and knowledge in achieving the organization's mission.

\begin{tabular}{|c|c|c|c|c|c|}
\hline $0 \%$ & $3.6 \%$ & $58.9 \%$ & $37.5 \%$ & 3.34 & 0.55 \\
\hline $1.8 \%$ & $7.1 \%$ & $64.3 \%$ & $26.3 \%$ & 3.16 & 0.63 \\
\hline $0 \%$ & $3.6 \%$ & $58.9 \%$ & $37.5 \%$ & 3.34 & 0.55 \\
\hline $0 \%$ & $7.1 \%$ & $39.3 \%$ & $53.6 \%$ & 3.46 & 0.63 \\
\hline $0 \%$ & $7.1 \%$ & $62.5 \%$ & $30.4 \%$ & 3.23 & 0.57 \\
\hline $1.8 \%$ & $8.9 \%$ & $57.1 \%$ & $32.1 \%$ & 3.20 & 0.67 \\
\hline $0 \%$ & $0 \%$ & $53.6 \%$ & $46.4 \%$ & 3.46 & 0.50 \\
\hline $0 \%$ & $3.6 \%$ & $73.2 \%$ & $23.2 \%$ & 3.20 & 0.48 \\
\hline $0 \%$ & $3.6 \%$ & $66.1 \%$ & $30.4 \%$ & 3.27 & 0.52 \\
\hline
\end{tabular}

$\begin{array}{llllll}0 \% & 3.6 \% & 60.7 \% & 35.7 \% & 3.32 & 0.54\end{array}$

$\begin{array}{llllll}0 \% & 1.8 \% & 67.9 \% & 30.4 \% & 3.29 & 0.49\end{array}$ 
12. We encourage organizational

$0 \%$ members to take calculated risks when applying their skills and knowledge.

13. We encourage organizational members to share their knowledge via Intranet or through the computerized network.

14. We consider organizational members' morale and possible human effects during the process of knowledge dissemination.

15. Managers mentor and coach those they lead.

16. Managers share up to date information via the computerized systems with organizational members about challenges, trends, and organizational decisions.

17. Managers ensure that the organizational actions and policies are consistent with its mission and general objectives.

18. There are systems to measure current and expected performance.

19. There is a systemic process to identify the learning outcomes for organizational members training.

20. Organizational members align their vision across different levels and departments.

21 . We encourage organizational members to think in terms of a broad picture or global perspective.

Knowledge storing and organization

22. The NPO uses two-way communication on a regular basis, such as through computerized network systems, emails or Intranet.

23. Organizational members have access to the needed information and knowledge at any time quickly and easily.

24. The NPO maintains an up-to-date database of organizational member's skills, knowledge and expertise.

$\begin{array}{llllll}1.8 \% & 5.4 \% & 53.6 \% & 39.3 \% & 3.30 & 0.69 \\ 0 \% & 5.4 \% & 60.7 \% & 33.9 \% & 3.29 & 0.49 \\ & & & & & \\ 0 \% & 3.6 \% & 58.9 \% & 37.5 \% & 3.34 & 0.55 \\ 1.8 \% & 3.6 \% & 53.6 \% & 41.1 \% & 3.34 & 0.64\end{array}$

$\begin{array}{llllll}0 \% & 0 \% & 51.8 \% & 48.2 \% & 3.48 & 0.63\end{array}$

$\begin{array}{llllll}3.6 \% & 16.1 \% & 53.6 \% & 26.8 \% & 3.04 & 0.76 \\ 3.6 \% & 23.2 \% & 51.8 \% & 21.4 \% & 2.91 & 0.77\end{array}$

$\begin{array}{llllll}0 \% & 16.1 \% & 50.0 \% & 33.9 \% & 3.18 & 0.69 \\ & & & & & \\ 1.8 \% & 10.7 \% & 58.9 \% & 28.6 \% & 3.14 & 0.67\end{array}$

$\begin{array}{llllll}0 \% & 0 \% & 57.1 \% & 42.9 \% & 3.43 & 0.50\end{array}$

$\begin{array}{llllll}0 \% & 19.6 \% & 48.2 \% & 32.1 \% & 3.13 & 0.72\end{array}$

$\begin{array}{llllll}1.8 \% & 7.1 \% & 50.0 \% & 41.1 \% & 3.30 & 0.69\end{array}$

Information derived from personal interviews also specified that OL practices implemented in their NPOs include knowledge acquisition, utilisation and storage. Essentially, these practices involved individual learning, team discussions, problem-solving and mentoring. Apart from these, the computerised networks that allow 
uploading of the evaluation reports of programmes and services were also widely mentioned by the respondents.

As illustrated by several respondents that:

"People learn best when they are grouped in teams....in this NPO, we shared what we know with each other so that better programmes and services can be generated." (Respondent J).

"It is through group discussions that knowledge and information can be acquired and disseminated throughout the NPO." (Respondent D).

"Mentoring approaches are often utilised in this NPO...I personally ensured that all junior staff are assigned a mentor, so that the skills and knowledge in serving our clients can be imparted." (Respondent B).

"Clients' profiles, involvement and programme's outcomes were better coordinated through the computerised systems, as it allows various case managers and other professional staff to have access to the necessary information in order to evaluate the effectiveness of our programmes. This has improved our internal communication processes as information flow is much more efficient and cases (clients) can be managed more effectively when the staff has access to their status of involvement.” (Respondent A).

As described by the respondents, the computerised systems allowed information on outcomes of programmes and services to be recorded systematically (knowledge acquisition) and could be reviewed (knowledge memory) by the respective managers or teams that are responsible for programmes implementation (knowledge utilisation). Similarly, it was reported by most of the survey respondents that the computerized network systems were effective two-way communication channels that allowed organizational members to access the needed information and knowledge at any time quickly and easily. These findings corresponded with the research findings of various scholars, where a LO has an integrative system to ensure that knowledge is captured, distributed and used for the purpose of organizational improvement (Watkins and Marsick, 1997; Feldman, 2000; Chou, 2005).

As the effectiveness and outcomes of programmes and services were recorded, future programmes and services could be developed by adopting some of the successful elements of these programmes and services. Moreover, a well implemented computerized network and knowledge management system allowed for the effective consolidation of tacit knowledge resided within the individual to be transformed into explicit forms (e.g., computerised documents, standard operating procedures, best practices or case files of clients etc). Hence, effective programmes and services that fulfil the needs of the clients can be generated. This finding coincided with the existing literature where systemic acquisition and utilisation of knowledge can enhance organizational performance and competitiveness, measured in terms of successful products development, innovation and strategies implementation (Lewis and Moultrie, 2005; Vera and Crossan, 2005; Debowski, 2006).

Other remarks which indicated the application of the computerised network and knowledge management system were also provided by the respondents as follows:

"Although there were challenges in getting the staff to use the computerised system in the initial phase...most of the staff have accepted the system now and are more willing to enter data as the system allows timely presentation of information and sharing of knowledge with other staff who require such data in their work." (Respondent E).

"Although we do not have a comprehensive knowledge management system like the business organizations; nevertheless, the NPO has taken a proactive approach in developing an Intranet system as well as the adaptation of the "Case Management System" developed by NCSS." (Respondent C).

"There was increased work efficiency among people as information is now segmented and stored in the databases...we were trained to upload and retrieve information from these online databases." (Respondent B).

"The use of corporate Intranet and databases allowed the NPOs to consolidate information promptly...this information was subsequently retrieved by the respective people for the purpose of reports generation, evaluation and tracking of clients' profiles and their involvement in the programmes and services." (Respondent $\mathrm{C}$ and $\mathrm{E}$ ).

These statements demonstrated the process of storing information and knowledge onto a computerised system, which in turn allowed organizational members to have access to information and knowledge on a timely basis. As stated by all the respondents that the computerised databases provided an added advantage in corporate management and distribution of information needed by both internal and external parties, i.e. donors, NCSS, government agencies. These systems allowed information and knowledge to be accessed throughout the NPOs, increasing efficiency of knowledge sharing and leading to substantial cost savings. As noted by several scholars, the outcomes of an effective information and knowledge management system can enhance work efficiency, 
reduce time in project coordination and paper documentations, which in turn will reduce operating and administrative expenses (Davenport, 1998; Emanuele et al., 2004). The findings obtained through both survey and personal interviews further affirmed the empirical findings of positive relationships between OL practices and business performance (Alavi and Leidner, 2001; Calantone et al., 2002; Sabherwal and Becerra-Fernandez, 2003; Lopez et al., 2005; Choy et al., 2006). In addition, this finding also implied the need to enhance the skills and knowledge of organizational members for effective utilisation of the computerised networks and knowledge management systems. It was also indicated by the respondents that the computerised networks and knowledge management systems allowed timely generation of information needed for accounts reporting and proposal submission, as donors and grants agencies expect timely submission of financial information and other corporate details in processing and approving funds application (Tinkelman, 1999; Parsons, 2003; Pharoah, 2008). Findings as such were supported by the existing literature, which held that computerised network and knowledge management systems designed for effective information and knowledge sharing would eventually contribute to overall reduction of administrative costs and increased operational efficiency (Sabherwal and Becerra-Fernandez, 2003; Susana et al., 2005; Rhodes et al., 2008). As a whole, this study has provided some empirical evidence that the investment into ICT can enhance the flow of information and knowledge within NPOs, for which research has been limited in this area.

\subsection{Clarity of Mission and Vision}

This element refers to the needs to develop a shared organizational vision and mission among organizational members in order to align the necessary resources and strategies in achieving the desirable outcomes. As shown in Table 11, all the respondents indicated that the existing organizational mission statements clearly reflect the functions of the NPOs. The findings also showed that majority of the NPOs have mission statements that identified the values with which all organizational members must conform. Moreover, majority of the respondents have indicated that they were able to communicate the NPOs' mission clearly to their clients. In line to ensure mission and vision clarity, the NPOs also performed self-assessments with respects to mission attainment.

Table 11. Descriptive analysis of clarity of mission and vision

\begin{tabular}{|c|c|c|c|c|c|c|c|}
\hline \multirow{2}{*}{\multicolumn{2}{|c|}{ Clarity of Mission and Vision }} & \multicolumn{4}{|c|}{ Responses } & \multirow[b]{2}{*}{ Mean } & \multirow[b]{2}{*}{ S.D } \\
\hline & & $\begin{array}{c}1= \\
\text { Strongly Disagree }\end{array}$ & $\begin{array}{c}2= \\
\text { Disagree }\end{array}$ & $\begin{array}{c}3= \\
\text { Agree }\end{array}$ & $\begin{array}{c}4= \\
\text { Strongly Agree }\end{array}$ & & \\
\hline & $\begin{array}{l}\text { There is widespread support and } \\
\text { acceptance of the NPO's mission } \\
\text { statement among the organizational } \\
\text { members. }\end{array}$ & $0 \%$ & $0 \%$ & $58.9 \%$ & $41.1 \%$ & 3.41 & 0.50 \\
\hline & $\begin{array}{l}\text { The NPO's mission statement } \\
\text { identifies values with which all } \\
\text { organizational members must } \\
\text { conform. }\end{array}$ & $0 \%$ & $1.8 \%$ & $46.4 \%$ & $51.8 \%$ & 3.50 & 0.54 \\
\hline & $\begin{array}{l}\text { The existing mission statement } \\
\text { clearly reflects the functions of the } \\
\text { NPO. }\end{array}$ & $0 \%$ & $0 \%$ & $33.9 \%$ & $66.1 \%$ & 3.66 & 0.48 \\
\hline & $\begin{array}{l}\text { We perform self-assessment with } \\
\text { respects to mission attainment. }\end{array}$ & $0 \%$ & $16.1 \%$ & $57.1 \%$ & $26.8 \%$ & 3.11 & 0.65 \\
\hline & $\begin{array}{l}\text { We understand how the mission of } \\
\text { the NPO is to be achieved. }\end{array}$ & $0 \%$ & $3.6 \%$ & $58.9 \%$ & $37.5 \%$ & 3.34 & 0.55 \\
\hline & $\begin{array}{l}\text { We are able to communicate the } \\
\text { NPOs' mission clearly to our clients. }\end{array}$ & $0 \%$ & $1.8 \%$ & $48.2 \%$ & $50.0 \%$ & 3.48 & 0.54 \\
\hline & $\begin{array}{l}\text { We share a common vision among } \\
\text { organizational members. }\end{array}$ & $0 \%$ & $7.1 \%$ & $53.6 \%$ & $39.3 \%$ & 3.32 & 0.61 \\
\hline & $\begin{array}{l}\text { My personal vision is similar to the } \\
\text { vision of the NPO. }\end{array}$ & $0 \%$ & $1.8 \%$ & $41.1 \%$ & $57.1 \%$ & 3.55 & 0.54 \\
\hline \multirow{2}{*}{\multicolumn{2}{|c|}{$\begin{array}{l}\text { 9. My personal vision contributes to the } \\
\text { attainment of the NPO's vision. }\end{array}$}} & $0 \%$ & $1.8 \%$ & $41.1 \%$ & $57.1 \%$ & 3.55 & 0.54 \\
\hline & & & & & Overall Mean & 3.44 & 0.55 \\
\hline
\end{tabular}


According to Pearce and David (1987) and Keyton (2005), mission and vision statements are essential organizational tools that can be used to promote the organizational values, culture and public awareness. It was also recommended by several scholars that in order to enforce the values of the organization, all organizational members must be able to recite the organizational mission correctly and openly. By doing so, the organizational members will tend to develop a greater sense of belonging towards the organization, and be effective in communicating the mission and vision of the organization to their respective stakeholders (Pearce and David, 1987; Bart and Tabone, 1998Schein, 2004). The findings further revealed that majority of the respondents (98\%) have personal visions that were similar to the NPOs' visions, whilst these personal visions were significant in contributing to the attainment of the NPO's visions. There was also a widespread support and acceptance of the NPO's mission statement among the organizational members, and people in the NPOs understand how the organizational mission is to be achieved. Essentially, the findings also revealed that the people in the NPOs shared a common vision. These findings coincided with the insights of Argyris and Shon (1978) who emphasised the important of consistency between personal and organizational vision and mission. Such a congruence of vision is also in keeping with the work of Luthan et al., (1994) who highlighted the role of vision and mission in creating commitment and support for organizational goals. From the performance measurement perspective, success of an NPO is based on its significant contribution toward the community in alignment with the organizational mission (Barrett, 2001; Henderson et al., 2002). Hence, it is important that the executive management understands and uphold these missions and be effective in communicating them to the respective stakeholders.

\subsection{Leadership Commitment and Empowerment}

This element presents leadership involvement as the fundamental component of a LO. Essentially, leaders' learning behaviour, commitment and empowerment towards learning and knowledge sharing were the focus of this element. As illustrated in Table 12, more than $80 \%$ of the NPOs have managers who often encouraged their organizational members to initiate changes that will bring benefits to the clients. Moreover, useful feedback was often provided by leaders to organizational members for problem-solving and decision-making purposes. It was further revealed in the findings that managers of the NPOs often functioned as coaches, teachers or educators for the other organizational members. Findings as such showed the intensity of leadership commitment imparting tacit knowledge to their subordinates. In terms of leaders' learning behaviours, the findings revealed that the NPO's managers were active learners and often led by example. It was also noted by the respondents that managers can accept criticism without becoming overly defensive. These findings implied a significant level of leadership commitment and empowerment in developing a positive learning culture among the NPOs that will eventually lead on to the development of a LO (Bass, 2000; Oliver and Kandadi, 2006; Amy, 2008).

Table 12. Descriptive analysis of leadership commitment and empowerment

\begin{tabular}{|c|c|c|c|c|c|c|c|}
\hline \multirow{3}{*}{\multicolumn{2}{|c|}{$\begin{array}{l}\text { Leadership Commitment and } \\
\text { Empowerment }\end{array}$}} & \multicolumn{4}{|c|}{ Responses } & \multirow{3}{*}{ Mean } & \multirow{3}{*}{ S.D } \\
\hline & & $1=$ & $2=$ & $3=$ & $4=$ & & \\
\hline & & Strongly Disagree & Disagree & Agree & Strongly Agree & & \\
\hline 1. & $\begin{array}{l}\text { Managers can accept criticism } \\
\text { without becoming overly defensive. }\end{array}$ & $0 \%$ & $7.1 \%$ & $69.6 \%$ & $23.2 \%$ & 3.16 & 0.53 \\
\hline & $\begin{array}{l}\text { Managers provide useful feedback to } \\
\text { help identify potential problems and } \\
\text { opportunities. }\end{array}$ & $0 \%$ & $5.4 \%$ & $55.4 \%$ & $39.3 \%$ & 3.34 & 0.58 \\
\hline 3. & $\begin{array}{l}\text { Managers involve organizational } \\
\text { members in important decisions. }\end{array}$ & $0 \%$ & $10.7 \%$ & $50.0 \%$ & $39.3 \%$ & 3.29 & 0.65 \\
\hline & $\begin{array}{l}\text { Managers often demonstrate multiple } \\
\text { roles such as coaches, teachers or } \\
\text { educators. }\end{array}$ & $0 \%$ & $10.7 \%$ & $41.1 \%$ & $48.2 \%$ & 3.38 & 0.68 \\
\hline 5. & $\begin{array}{l}\text { Managers encourage changes that } \\
\text { will bring benefits to the clients. }\end{array}$ & $0 \%$ & $5.4 \%$ & $50.0 \%$ & $44.6 \%$ & 3.39 & 0.59 \\
\hline 6. & $\begin{array}{l}\text { Managers are active learners and } \\
\text { often lead by example. }\end{array}$ & $0 \%$ & $1.8 \%$ & $69.6 \%$ & $28.6 \%$ & 3.27 & 0.49 \\
\hline \multirow{2}{*}{\multicolumn{2}{|c|}{$\begin{array}{l}\text { 7. Managers empower organizational } \\
\text { members in decision-making. }\end{array}$}} & $1.8 \%$ & $16.1 \%$ & $53.6 \%$ & $28.6 \%$ & 3.09 & 0.72 \\
\hline & & & & & Overall Mean & 3.27 & 0.61 \\
\hline
\end{tabular}




\subsection{Experimentation and Intrinsic Motivation}

This element identifies experimentation as an essential strategy for learning and innovation, which also include learning from failures and mistakes. In addition, intrinsic motivation was also suggested as important factors for people working in the NPOs. Specifically, as illustrated in Table 13, NPO's managers paid attention to the new ideas suggested by the organizational members, whilst they were also encouraged to bring new ideas into the NPOs. Moreover, organizational members were encouraged to perform work experimentation in order to improve their performance, and failures were often constructively discussed in the NPOs. On the aspect of intrinsic motivation, the findings showed that personal recognition, encouragement and mission fulfilment are important motivating factors for people working in the NPOs. In reference to the findings presented on individual learning practices and team learning practices, monetary rewards for learning were less practiced among the NPOs. These findings affirmed that the majority of the NPOs practiced intrinsic-based motivation, which include providing personal recognition and management encouragement for their organizational members.

Table 13. Descriptive analysis of experimentation and intrinsic motivation

\begin{tabular}{|c|c|c|c|c|c|c|c|}
\hline & \multirow[b]{2}{*}{$\begin{array}{c}\text { Experimentation and intrinsic } \\
\text { motivation }\end{array}$} & \multicolumn{4}{|c|}{ Responses } & \multirow[b]{2}{*}{ Mean } & \multirow[b]{2}{*}{ S.D } \\
\hline & & $\begin{array}{c}1= \\
\text { Strongly Disagree }\end{array}$ & $\begin{array}{c}2= \\
\text { Disagree }\end{array}$ & $\begin{array}{c}3= \\
\text { Agree }\end{array}$ & $\begin{array}{c}4= \\
\text { Strongly Agree }\end{array}$ & & \\
\hline 1. & $\begin{array}{l}\text { Organizational members are } \\
\text { encouraged to bring new ideas into } \\
\text { the NPO. }\end{array}$ & $0 \%$ & $3.6 \%$ & $41.1 \%$ & $55.4 \%$ & 3.52 & 0.57 \\
\hline 2. & $\begin{array}{l}\text { Organizational members are } \\
\text { encouraged to perform work } \\
\text { experimentation in order to } \\
\text { improve their performance. }\end{array}$ & $0 \%$ & $5.4 \%$ & $64.3 \%$ & $30.4 \%$ & 3.25 & 0.55 \\
\hline 3. & $\begin{array}{l}\text { New organizational members are } \\
\text { allowed to question the way things } \\
\text { are done in the NPO. }\end{array}$ & $0 \%$ & $5.4 \%$ & $66.1 \%$ & $28.6 \%$ & 3.23 & 0.54 \\
\hline 4. & $\begin{array}{l}\text { Failures are often constructively } \\
\text { discussed in the NPO. }\end{array}$ & $0 \%$ & $8.9 \%$ & $62.5 \%$ & $28.6 \%$ & 3.20 & 0.59 \\
\hline 5. & $\begin{array}{l}\text { Managers give attention to new } \\
\text { ideas suggested by all } \\
\text { organizational members. }\end{array}$ & $0 \%$ & $8.9 \%$ & $46.4 \%$ & $44.6 \%$ & 3.36 & 0.64 \\
\hline 6. & $\begin{array}{l}\text { The management rewards } \\
\text { innovative ideas that work. }\end{array}$ & $1.8 \%$ & $19.6 \%$ & $51.8 \%$ & $26.8 \%$ & 3.04 & 0.74 \\
\hline 7. & $\begin{array}{l}\text { Organizational members in the } \\
\text { NPO view personal recognition, } \\
\text { encouragement and fulfilling of } \\
\text { mission as part of their reward. }\end{array}$ & $0 \%$ & $5.4 \%$ & $48.2 \%$ & $46.4 \%$ & 3.41 & 0.60 \\
\hline
\end{tabular}

Overall Mean $3.29 \quad 0.60$

\subsection{Effective Transfer of Knowledge}

This element refers to the significant of knowledge transfer within a LO. Essentially, multi-dimensional approaches of knowledge transfer were recommended, which include two-ways communication, mentoring and learning from the best practices of other NPOs. As shown in Table 14, more than $60 \%$ of the respondents indicated that people in the NPOs shared knowledge with each other, whilst tacit knowledge is often transformed into written forms, such as "standard operating procedures" and reports stored in the computerized network and knowledge management system which allowed for access by organizational members. The findings also showed that the NPOs have a system that allowed organizational members to learn successful practices from other NPOs. In addition, organizational members trusted and respected the knowledge shared by each other. 
Table 14. Descriptive analysis of effective transfer of knowledge

\begin{tabular}{|c|c|c|c|c|c|c|c|}
\hline \multirow{2}{*}{\multicolumn{2}{|c|}{ Effective Transfer of Knowledge }} & \multicolumn{4}{|c|}{ Responses } & \multirow[b]{2}{*}{ Mean } & \multirow[b]{2}{*}{ S.D } \\
\hline & & $\begin{array}{c}1= \\
\text { Strongly Disagree }\end{array}$ & $\begin{array}{c}2= \\
\text { Disagree }\end{array}$ & $\begin{array}{c}3= \\
\text { Agree }\end{array}$ & $\begin{array}{c}4= \\
\text { Strongly Agree }\end{array}$ & & \\
\hline 1. & $\begin{array}{l}\text { The NPO has a system that allows } \\
\text { organizational members to learn } \\
\text { successful practices from other } \\
\text { NPOs. }\end{array}$ & $0 \%$ & $40.0 \%$ & $49.1 \%$ & $10.9 \%$ & 3.32 & 0.58 \\
\hline 2. & $\begin{array}{l}\text { Organizational members are } \\
\text { encouraged to share knowledge } \\
\text { with each other. }\end{array}$ & $0 \%$ & $39.3 \%$ & $44.6 \%$ & $16.1 \%$ & 3.39 & 0.59 \\
\hline 3. & $\begin{array}{l}\text { Organizational members gather } \\
\text { information and new knowledge } \\
\text { that are useful to their work. }\end{array}$ & $0 \%$ & $5.4 \%$ & $58.9 \%$ & $35.7 \%$ & 2.71 & 0.65 \\
\hline 4. & $\begin{array}{l}\text { Knowledge is transformed into } \\
\text { written forms, such as 'standard } \\
\text { operating procedure' stored in the } \\
\text { knowledge management system } \\
\text { and allows access by all } \\
\text { organizational members. }\end{array}$ & $0 \%$ & $23.2 \%$ & $60.7 \%$ & $16.1 \%$ & 3.30 & 0.57 \\
\hline 5. & $\begin{array}{l}\text { Knowledge sharing is common } \\
\text { among organizational members } \\
\text { and across departments. }\end{array}$ & $0 \%$ & $10.7 \%$ & $60.7 \%$ & $28.6 \%$ & 2.93 & 0.63 \\
\hline 6. & $\begin{array}{l}\text { Organizational members trust and } \\
\text { respect the knowledge shared by } \\
\text { each other. }\end{array}$ & $0 \%$ & $8.9 \%$ & $67.9 \%$ & $23.2 \%$ & 3.18 & 0.61 \\
\hline 7. & $\begin{array}{l}\text { Organizational members seek } \\
\text { opportunities to discuss the } \\
\text { successful programmes and } \\
\text { services and evaluate the factors } \\
\text { for success. }\end{array}$ & $0 \%$ & $5.4 \%$ & $57.1 \%$ & $37.5 \%$ & 3.14 & 0.55 \\
\hline 8. & $\begin{array}{l}\text { New work processes that may be } \\
\text { useful to the NPO are usually } \\
\text { shared with all organizational } \\
\text { members. }\end{array}$ & $0 \%$ & $5.4 \%$ & $50.0 \%$ & $44.6 \%$ & 2.77 & 0.71 \\
\hline
\end{tabular}

Essentially, organizational members seek opportunity to discuss the successful programmes and services and understand the factors leading to the success. The aforementioned findings coincided with the earlier discussion over OL practices, where management support in learning, knowledge sharing, and two-ways communication were noted by majority of the respondents as the most commonly practiced LOE. However, the findings showed that new knowledge and processes were not widely utilised in the NPOs. Furthermore, knowledge sharing should be further enforced among organizational members and across departments. Nevertheless, the findings showed that the majority of the NPOs were supportive towards a multi-dimensional approach of knowledge transfer.

\subsection{Team Problem-Solving}

This LOE refers to an organizational design that encourages joint problem-solving, openness and trust, shared decision-making and the empowerment of teams and individuals. The findings as depicted in Table 15 revealed that team problem-solving enhanced teamwork, transfer of knowledge and organizational performance. Moreover, organizational members were encouraged to solve problems together before discussing them with the managers. They were also encouraged to impart different skills and talents into the process of problem-solving. Based on the findings, informal groups were also formed to solve problems in the NPOs. These results coincided 
with the findings presented earlier on team learning practices, where teamwork and joint decision-making were common practices in the NPOs.

Table 15. Descriptive analysis of team problem-solving

\begin{tabular}{|c|c|c|c|c|c|c|}
\hline \multirow{3}{*}{ Team Problem-Solving } & \multicolumn{4}{|c|}{ Responses } & \multirow{3}{*}{ Mean } & \multirow{3}{*}{ S.D } \\
\hline & $1=$ & $2=$ & $3=$ & $4=$ & & \\
\hline & Strongly Disagree & Disagree & Agree & Strongly Agree & & \\
\hline $\begin{array}{l}\text { 1. Organizational members are } \\
\text { encouraged to solve problems with } \\
\text { their peers before discussing them } \\
\text { with the manager. }\end{array}$ & $0 \%$ & $3.6 \%$ & $66.1 \%$ & $30.4 \%$ & 3.27 & 0.52 \\
\hline $\begin{array}{l}\text { 2. Organizational members are } \\
\text { encouraged to impart different skills } \\
\text { and talents in problem-solving. }\end{array}$ & $0 \%$ & $7.1 \%$ & $64.3 \%$ & $28.6 \%$ & 3.21 & 0.56 \\
\hline $\begin{array}{l}\text { 3. Team problem-solving enhances } \\
\text { teamwork and knowledge transfer in } \\
\text { the NPO. }\end{array}$ & $0 \%$ & $8.9 \%$ & $51.8 \%$ & $39.3 \%$ & 3.30 & 0.63 \\
\hline $\begin{array}{l}\text { 4. Team problem-solving enhances } \\
\text { organizational performance. }\end{array}$ & $0 \%$ & $10.7 \%$ & $46.4 \%$ & $42.9 \%$ & 3.32 & 0.66 \\
\hline $\begin{array}{l}\text { 5. Organizational members of different } \\
\text { skills and departments are gathered } \\
\text { for problem-solving. }\end{array}$ & $1.8 \%$ & $17.9 \%$ & $57.1 \%$ & $23.2 \%$ & 3.02 & 0.70 \\
\hline $\begin{array}{l}\text { 6. There are various informal groups } \\
\text { formed to solve problems in the } \\
\text { NPO. }\end{array}$ & $0 \%$ & $25.0 \%$ & $44.6 \%$ & $30.4 \%$ & 3.05 & 0.75 \\
\hline \multirow{2}{*}{$\begin{array}{l}\text { 7. Team problem-solving helps to } \\
\text { facilitate communication and transfer } \\
\text { of knowledge in the NPO. }\end{array}$} & $0 \%$ & $5.4 \%$ & $58.9 \%$ & $35.7 \%$ & 3.30 & 0.57 \\
\hline & & & & Overall Mean & 3.21 & 0.63 \\
\hline
\end{tabular}

Through the interviews, participants also indicate that team problem-solving was also an important LOE for their NPOs. Essentially, all the respondents revealed that problem-solving through multi-disciplinary teams allowed organizational members with different expertises to be gathered for effective problem-solving and decision-making. As mentioned by several scholars, a LO allows problems to be systematically diagnosed and resolved by the respective organizational members (Watkins et al., 1993; Senge et al., 1994; Chodak, 2001). It was also noted by the respondents that team problem-solving allowed multi-tasking practices within the NPOs. There were also comments from the respondents which suggest that team problem-solving helps to maximise the potential of existing manpower and leads to better management of human resources.

Some of the relevant comments extracted from the interview data were as follows:

"The use of teams has allowed staff with multiple-skills and knowledge to work closely together. This has created opportunities for teamwork and knowledge sharing, which enhances the overall problem-solving effectiveness." (Respondent A).

"Team problem-solving practices helped to consolidate the resources (both manpower and information) efficiently...hence, solutions could be generated appropriately to address the issues... as a result, contributing towards greater operational efficiency." (Respondent I).

"I constantly receive feedback from my clients that several team members whom they came in contact with were able to provide the necessary guidance and information they needed...essentially, this close interaction between clients and team members allowed more intensive and personal services to be provided to the clients, which in turn contributed to a higher-level of client's satisfaction." (Respondent B). 
"Being a non-profit voluntary organization, we need to ensure that programmes are organised to fulfil the needs of the clients. In many occasions, teams can be formed that consist of professional staff and volunteers. This has created an opportunities to extent the potential of the existing manpower, as well as tapping onto external sources of knowledge provided by the volunteers." (Respondent D).

"Being a small scale NPO, we need different expertises from people in order to function effectively. Teams indeed have been a useful approach in gathering people with a variety of skills and knowledge to work together. In addition, multi-tasking among team members have been observed as they apply their skills widely and across functions." (Respondent G).

With reference to the literature of team problem-solving, participatory decision-making tends to produce higher levels of cohesiveness among organizational members (Imber and Neidt, 1990; Sabo and Fusco, 2002), which potentially contribute to higher-level of team commitment and effectiveness in problem-solving (Elkjaer, 2003; Sabherwal and Becerra-Fernandez, 2003). As a whole, responses obtained from the interviews substantiated the survey findings of a significant relationship between team problem-solving and non-financial performance of NPOs.

In summary of the findings obtained from personal interviews, one of the most important themes that emerged from the interviews was that individual learning practices, whether in the form of formal or informal approaches seemed to enhance the overall organizational performance. This theme in particular implies that in order for a LO to be developed, support and proactive learning attitudes must be stimulated throughout the NPO, which was substantially supported by the literature of LO (Kim, 1993; McDougall and Beattie, 1998; Sabherwaland Becerra-Fernandez, 2002).

Apart from individual learning, themes related to knowledge acquisition and computerised databases were also mentioned by the respondents. Throughout the literature, studies have clearly indicated the importance of knowledge management in order to develop a LO (Scarborough and Swan, 2003; Sun and Scott, 2003; Chou, 2005; Thomas and Allen, 2006). This in turn suggests that the creation of a LO is not a random process, but requires commitment from the management in resource allocation and taking it as a strategic direction of NPOs so that the appropriate learning and knowledge sharing practices can be enforced among the organizational members. The findings also implies that in this electronic era, all organizational members are expected to understand and use the Intranet, email system and established databases for the purpose of information and knowledge sharing. Constant upgrading of skills to maintain the expertise in using these technologies will then be highly essential in order for the established knowledge databases to be fully utilised. According to several scholars, the regular enhancement of ICT skills is important for any organizations that aim to remain effective in this era of technology advancement (Choi and Lee, 2002; Wong and Aspinall, 2003; Gottschalk, 2005). What is important now for all organizational members is to become IT savvy in order to utilise the consolidated knowledge for the benefit of the organization.

The other important themes that emerged from the interviews were team collaboration, mentoring, and team problem-solving. Specifically, the utilisation of teams allows full-time staff and volunteers to share their expertise in designing and delivering the NPO's programmes and services. Mentoring facilitates the transfer of tacit knowledge, while team problem-solving helps to resolve clients' problems and/ or other issues efficiently (Sosik and Lee; 2002; Smith et al., 2005). These themes highlighted the significance of social/ relational learning in the development of a LO, where learning takes place among people through regular communication; open sharing of information and knowledge, practice teamwork and collaboration (Gheradi et al., 1998; Elkjaer, 2003; Gupta and Govindarajan, 2000). Essentially, knowledge acquired from individuals and teams is purposefully consolidated so that other people can have access to them. As a whole, the findings also imply a need to create a strong learning culture within the NPO, which has been mentioned in the literature as an important element for the successful development of a LO (Cook and Yanow, 1993; Popper and Lipshit, 2000; Barrett, 2001; Woodbury, 2006).

\section{Conclusion}

The main contribution of this study towards knowledge was an advancement of the current available knowledge about LOE and the performance of NPOs. It is the first research that has been conducted amongst the non-profit sectors of Singapore specifically on human social services organization, and findings of this study could enhance the understanding on how the concept of LO can contribute to NPOs' performance. In this study, the increasing demand for performance measures in NPOs demonstrated the need to ensure proper utilisation of charity funds and donations for the benefits of the clients and community. However, the area of performance measurement is complex and more studies are needed. Through a comprehensive literature review, relevant performance 
indicators (financial and non-financial) were recommended in this study. Hence, the study makes an important contribution in this area of study. These performance indicators can also be used for future research. As a result of this study, specific strategies were recommended to the NPOs towards becoming a LO.

There were also several significant research implications. Specifically, NPOs' managers may want to encourage continual learning by sending its employees for relevant training programmes in order to enhance their skills and competencies. As mentioned by the respondents, programme and service's quality and effectiveness can be enhanced through regular reviews of programmes and services. Therefore, NPOs' manager may need to consider organising regular feedback and evaluation sessions in order for its employees to discover new insights in programmes and services design and its implementation, while taking the opportunity to share their knowledge and experiences.

Another practical implication of this study would be to organise its employees into teams as to allow effective communication, problem-solving and decision-making. Essentially, the results of this study implied the effective utilisation of multi-disciplinary teams in providing programmes and services. Furthermore, the significant relationship between OL practices and the overall performance of NPOs also signal the need for investment in ICT to acquire, disseminate and organise knowledge within the NPOs. These findings thus suggest that ICT development is a critical factor in the performance of NPOs. As such, NPOs and their relevant stakeholders must not assume the development of ICT to be a secondary priority, but rather regard it as a vital development of NPOs.

The research finding also implied that a comprehensive approach is needed for a LO to be developed. As mentioned by various scholars, LO development relies on a process-oriented approach with a system to acquire and utilise knowledge to ensure its successful creation (Goodman and Darr, 1996; Watkins and Marsick, 1997; Goh and Richards, 1997; Bourne and Walker, 2004). NPOs that engage in knowledge sharing, team problem-solving and implementing OL practices will be able to better achieve their missions as effective human social service organizations.

Due to the complexity of the research framework and given that LO is a relatively new concept in the non-profit sectors, it may be necessary for the study to be conducted within a larger and more diverse sample. On this note, future researchers may wish to examine the concept of LO incorporated in this research framework across the non-profit sectors by including the arts, sports or NPOs of other nature. Research as such might be able to improve "generalizability" if a wider population were surveyed. Such endeavours have great potential to advance the understanding of LO and may contribute to the development of a more robust theory. These limitations, however, represent opportunities for future studies.

A comparative study could be undertaken among NPOs from different sectors with the objective of uncovering the effects of LO in improving organizational performance. Such an extension may be worthwhile to determine if the findings can be replicated. Additional modifications would need to be made on the survey instruments, particularly on the measurement of performance, depending on the type of NPOs. It would also be insightful to conduct the research on NPOs in other countries. Such explorations have great potential in advancing the theory of LO.

Another worthwhile challenge for future researchers is to develop a richer explanation of how other NPOs learn in various non-profit sectors. Perhaps an empirical study into how knowledge is acquired, disseminated, utilised and stored has great potential in shedding some light on this important practices of OL. Pragmatic knowledge that bridges these gaps in the LO literature could potentially benefit the NPOs that intent to becoming LOs. More longitudinal studies across the non-profit sectors can also be conducted in order to better assess the relationship between LOE and the performance of NPOs. Cross-cultural assessments would also help to establish whether the relationship between LOE and performance of NPOs is consistent across different organizational cultures.

Lastly, the implications for effective ICT and knowledge management systems determined in this study have profound significance on the nature of knowledge sharing and utilisation within the NPOs. Research that examines relationships between effective development and utilisation of knowledge management and NPOs' performance would be very valuable for leaders of NPOs to devote resources for its strategic development. With a better understanding of the implications of these empirical studies, practitioners might be able to design LO strategies to maximise NPOs' performance.

\section{References}

Abzug, R., \& Turnheim, J. K. (1998). Bandwagon or band-aid? A model of non-profit in corporation by state. Non-Profit and Voluntary Sector Quarterly, 27, 300-322. http://dx.doi.org/10.1177/0899764098273003 
Ahmed, P. K., Lim, K. K., \& Loh, A. Y. E. (2002). Learning through knowledge management. Oxford: Butterworth-Heinemann.

Alavi, M., \& Leidner, D. E. (2001). Knowledge management and knowledge management systems: Conceptual foundations and research issues. MIS Quarterly, 25(1), 107-136. http://dx.doi.org/10.2307/3250961

Amy, H. A. (2008). Leaders as facilitators of individual and organizational learning. Leadership and Organizational Development Journal, 29(3), 212-234. http://dx.doi.org/10.1108/01437730810861281

Anthony, R. N., \& Herzlinger, R. E. (1975). Management control in NPOs. Homewood, Illinois: Richard D. Irwin, Inc.

Argote, Linda., \& Paul Ingram. (2000). Knowledge transfer: A basis for competitive advantage in firms. Organizational Behaviour and Human Decision Processes, 82(1), 150-169. http://dx.doi.org/10.1006/obhd.2000.2893

Argyris, C., \& Schon, D. (1978). Organizational learning: A theory of action perspective. Reading, M.A.: Addison-Wesley.

Argyris, C., \& Schon, D. (1996). Organizational learning II: Theory, method, and practice. Reading, M.A.: Addison-Wesley.

Armstrong, M., \& Baron, A. (2003). Performance management: The new realities. Chartered Institute of Personnel and Development.

Baldwin, T. T., \& Danielson, C. C. (2002). Invited reaction: Linking learning with financial performance. Human Resource Development Quarterly, 13(1), 23-9. http://dx.doi.org/10.1002/hrdq.1011

Bamberger, M. Rugh, J., Church, M., \& Fort, L. (2004). Shoestring evaluation: Designing impact evaluations under budget, time and data constraints. American Journal of Evaluation, 25(1), 5-37.

Barnard, G. (2004). The new frontier: Evaluation and organizational learning. Retrieved from www.euforic.org

Barrett, F. J. (2001). Creating appreciative learning cultures. Organizational Dynamics, 24(2), 36-49. http://dx.doi.org/10.1016/0090-2616(95)90070-5

Bart, C. K., \& Tabone, J. C. (1998). Mission statement rationales and organizational alignment in the not-for-profit health care sector. Health Care Management Review, 23, 54-70.

Bass, B. M. (2000). The future of leadership in learning organizations. Journal of Leadership Studies, 7(3), 18-40. http://dx.doi.org/10.1177/107179190000700302

Beeby, M., \& Booth, C. (2000). Networks and inter-organizational learning: A critical review. The Learning Organization, 7(2), 75-88. http://dx.doi.org/10.1108/09696470010316260

Beer, M., Voelpel, S. C., Leibold, M., \& Tekie, E. B. (2005). Strategic management as organizational learning: Developing fit and alignment through a disciplined process. Long Range Planning, 38, 445-465. http://dx.doi.org/10.1016/j.lrp.2005.04.008

Billis, D., \& Glennerster, H. (1998). Human service delivery and the voluntary sector: Towards a theory of $\begin{array}{lllll}\text { comparative advantage. Journal of Social Policy, } & \text { 27(1), } & \text { 79-98. }\end{array}$ http://dx.doi.org/10.1017/S0047279497005175

Boland, T., \& Fowler, A. (2000). A systems perspective of performance management in public sector organization. International Journal of Public Sector Management, 13(5), 417-446. http://dx.doi.org/10.1108/09513550010350832

Bolton, M., \& Abdy, M. (2003). Leadership, leadership, leadership. London: ACEVO/NCVO.

Bontis, N., Crossan, M., \& Hulland, J. (2002). Managing an organizational learning system by aligning stocks and flows (electronic version). Journal of Management Studies, 39(4), 437-469. http://dx.doi.org/10.1111/1467-6486.t01-1-00299

Bourne, L., \& Walker, G. H. (2004). Advancing project management in learning organizations. The Learning Organization, 11(3), 226-243. http://dx.doi.org/10.1108/09696470410532996

Bozzo, S. L. (2000). Evaluation resources for non-profit organizations. Non-Profit Management and Leadership, 10, 463-472. http://dx.doi.org/10.1002/nml.10409

Brown, L. D., \& Kalegaonkar, A. (2002). Support organizations and the evolution of the NGO sector. Non-Profit and Voluntary Sector Quarterly, 31(2), 231-258. 
Brudney, J. L., \& Golec, R. R. (1997). Organizational benchmarks, impact, and effectiveness assessments: Closing the measurement circle in Independent Sector (PP. 33-46). Washington, D.C.: Independent Sector.

Bryson, J. (1995). Strategic Planning for Public and Non-Profit Organizations: A Guide to Strengthening and Sustaining Organizational Achievement. San Francisco: Jossey-Bass Publishers.

Calantone, R. J., Cavusgil, S. T., \& Zhao, Y. (2002). Learning orientation: Firm innovation capability, and firm $\begin{array}{llll}\text { performance. Industrial } \quad \text { Marketing } & \text { Management, }\end{array}$ http://dx.doi.org/10.1016/S0019-8501(01)00203-6

Calgary Chamber of Voluntary Organizations (CCVO). (2006). Human Resources Issues for Alberta's Nonprofits.

Chang, C. F., \& Tuckman, H. P. (1991). Methodology for measuring the financial vulnerability of charitable non-profit organizations. Non-profit and Voluntary Sector Quarterly, 20, 445-460. http://dx.doi.org/10.1177/089976409102000407

Child, J. (2003). Organizational learning. In Faulkner, D.O. and Campbell, A. (Eds). The Oxford Handbook of Strategy (pp. 437-465). Oxford: Oxford University Press.

Chodak, M. (2001). The Call for Learning Organization. Retrieved from http://www.rec.org/REC/Programs/EMTC/Insight/vol12/learning.html

Choi, B., \& Lee, H. (2002). An empirical investigation of KM styles and their effect on corporate performance. Information and Management.

Chou, S. W. (2005). Knowledge creation: Absorptive capacity, organizational mechanisms, and knowledge storage/ retrieval capabilities. Journal of Information Science, 31(6), 453-465. http://dx.doi.org/10.1177/0165551505057005

Choy, C. S., Yew, W. K., \& Lim, B. (2006). Criteria for measuring KM performance outcomes in organizations. Industrial Management \& Data System, 7(106), 917-936. http://dx.doi.org/10.1108/02635570610688850

Chryssochoidis, G. M., \& Wong, V. (2000). Service innovation multi-country launch: Causes of delays. European Journal of Innovation Management, 3, 35-44. http://dx.doi.org/10.1108/14601060010305247

Colbert, B. A. (2004). The complex resource-based view: Implications for theory and practice in strategic human resource management. Academy of Management Review, 29(3), 341-358.

Cook, S. D. N., \& Yanow, D. (1993). Culture and organizational learning. Journal of Management Inquiry, 2(4), 373-390. http://dx.doi.org/10.1177/105649269324010

Costa, J., Teare, R., Vaughan, R., \& Edwards, J. (1997). A review of the process of environmental scanning in the context of strategy making. In Teare, R., Farber Canziani, B., \&Brown, G. (Eds.), Global Directions: New Strategies for Hospitality and Tourism (pp. 5-38). London: Cassell.

Crittenden, W. F., Crittenden, V., Stone, M. M., \& Robertson, C. J. (2004). An uneasy alliance: Planning and performance in non-profit organizations. International Journal of Organizational Theory and Behaviour, 7(1), 81-106.

Crossan, M. M., \& Berdrow, I. (2003). Organizational learning and strategic renewal. Strategic management Journal, 24(11), 1087-1130. http://dx.doi.org/10.1002/smj.342

Davenport, T., \& Prusak, L. (1998). Working knowledge: How organizations manage what they know. Boston, M.A.: Harvard Business School Press.

Debowski, S. (2006). Knowledge Management. John Wiley \& Sons Australia, Ltd, Melbourne.

Dierkes, M., Antal, A. B., Child, J., \& Nonaka, I. (2000). Handbook of organizational learning and knowledge. Oxford.: Oxford University Press.

Drucker, P. F. (1990). What business can learn from nonprofits? In Oster, S. M. (1994), Management of non-profit organizations (pp. 88-93). Brookfield, V.T.: Dartmouth.

Durtina, R. E. (1984). Measurement preconditions for assessing non-profit performance: An exploratory study. The Government Accountants Journal, Summer, 13-19.

Dymock, D., \& McCarthy, C. (2006). Towards a learning organization? Employee perceptions. The learning Organization, 13(5), 525-536. http://dx.doi.org/10.1108/09696470610680017

Easterby-Smith, M. (1997). Organizational learning: Diverging community of practice? Management Learning, 
29(3).

Easterby-Smith, M. Snell, R., \& Gherardi, S. (1998). Organizational learning: Diverging communities of practice? Management Learning, 29(3), 259-272. http://dx.doi.org/10.1177/1350507698293001

Easterby-Smith, M., Burgoyne, J., \& Araujo, L. (2001). Organizational learning and the learning organization. London: Sage.

Edmonson, A. (1999). Psychological safety and learning behaviours in work teams. Administrative Science Quarterly, 40(2), 350-384. http://dx.doi.org/10.2307/2666999

Eisenhardt, K. M., \& Martin, J. A. (2000). Dynamic capabilities: What are they? Strategic Management Journal, 21, 1105-1121. http://dx.doi.org/10.1002/1097-0266(200010/11)21:10/11<1105::AID-SMJ133>3.0.CO;2-E

Elaine, M., Elisa, V., \& Harry, P. H. (2001). Outcome measurement in non-profit organizations: Current practices and recommendations. Independent Sector.

Elkjaer, B. (2003). Social learning theory: Learning as participation in social processes. In Easterby-Smith, M., \& Lyles, M. A. (Eds.), The Blackwell Handbook of Organizational Learning and Knowledge Management (pp. 38-53). Malden, M.A.: Blackwell.

Emanuele, L. Francesca, B., \& Alberto, S. (2004). Knowledge management in non-profit organizations. Journal of Knowledge Management, 8(6), 16-30. http://dx.doi.org/10.1108/13673270410567602

Entrekin, L., \& Court, M. (2001). Human resource management: Adaptation and change in an age of globalization. Geneva: International Labour Office.

Erik, K. (2006). Measuring quality in services for children with an intellectual disability. International Journal of Health Care Quality Assurance, 19(5), 400-480. http://dx.doi.org/10.1108/09526860610680049

Fahey, L., \& V. Narayanan. (1986). Macro-environmental analysis for strategic management. West Publishing Company.

Feldman, M. S. (2000). Organizational routines as a source of continuous change. Organization Science, 11, 611-629. http://dx.doi.org/10.1287/orsc.11.6.611.12529

Feller, I. (2002). Performance measurement. American Journal of Evaluation, 24, 435-452.

Fine, A. H., Thayer, C. E., \& Coghlan, A. T. (2000). Program evaluation practice in the non-profit sector. Non-Profit Management and Leadership, 10(3), 331-339. http://dx.doi.org/10.1002/nml.10309

Finger, M., \& Burgin Brand, S. (1999). The concept of the learning organization applied to the transformation of the public sector. In M. Easterby-Smith, J. B., \& Araujo, L. (Eds.), Organizational learning and the learning organization: Developments in theory and practice (pp. 130-156). London: Sage. http://dx.doi.org/10.4135/9781446218297.n8

Fitzpatrick, J. L., Sanders, J., \& Worthen, B. (2004). Programme evaluation: Alternative approached and practical guidelines (3rd ed.). Boston: Allyn and Bacon.

Flynn, N. (1986). Performance measurement in public sector services. Policy and politics, 14(3), 389-404. http://dx.doi.org/10.1332/030557386782628172

Friedman, V. J., Lipshitz, R., \& Popper, M. (2005). The mystification of organizational learning. Journal of Management Inquiry, 14, 19-30. http://dx.doi.org/10.1177/1056492604273758

Gainer, B., \& Padanyi, P. (2004). The relationship between market-orientated activities and market-orientated culture: Implications for the development of market orientation in non-profit organizations. Journal of Business Research, 58(6), 854-862. http://dx.doi.org/10.1016/j.jbusres.2003.10.005

Garvin, D. (1993). Building a learning organization. Harvard Business School Press, (July-Aug), 78-91.

Gheradi, S. Nicolini, D., \& Odella, F. (1998). Toward a social understanding of how people learn in organization. Management Learning, 29(3), 273-297. http://dx.doi.org/10.1177/1350507698293002

Glynn, J. J., \& Murphy, M. P. (1996). Failing accountabilities and failing performance review. International Journal of Public Sector Management, 9(5/6), 125-137. http://dx.doi.org/10.1108/09513559610146492

Goh, S. C., \& Richards, G. (1997). Benchmarking the learning capability of organization. European Management Journal, 15(5), 575-583. http://dx.doi.org/10.1016/S0263-2373(97)00036-4

Goh, S. C., \& Ryan, P. J. (2002). Learning capability, organizational factors and firm performance. Paper presented at the $3^{\text {rd }}$ European Conference on Organizational Knowledge. Learning and Capabilities, Athens. 
Goodman, P. S., \& Darr, E. D. (1996). Exchanging best practices through computer aided systems. Academy of Management Executive, 10(2), 7-19. http://dx.doi.org/10.5465/AME.1996.9606161549

Gottschalk, P. (2005). Strategic Knowledge Management Technology. London: Idea Group Publishing.

Graham, C. M., \& Nafukho, F. M. (2007). Employees' perception toward the dimension of culture in enhancing organizational learning. The Learning Organization, 14(3), 281-292. http://dx.doi.org/10.1108/09696470710739435

Gupta, A. K., \& Govindarajan, V. (2000). Knowledge management's social dimension: Lessons from Nucor Steel. Sloan management Review, 42(1), 71-80.

Gupta, A., \& Michailova, S. (2004). Knowledge sharing in knowledge intensive firms. CKG.

Hamel, G. (1997). The search for strategy. Retrieved from www.strategasnet.com

Hansen, M. T. (2002). Knowledge networks: Explaining effective knowledge sharing in Multiunit companies. Organizational Science, 13(3), 232-248. http://dx.doi.org/10.1287/orsc.13.3.232.2771

Hardaker, M., \& Ward, B. (1987) Getting things done: How to make a team work. Harvard Business Review, 65, 112-119.

Henderson, D., Chase, B., \& Woodson, B. (2002). Performance measures for NPOs. Journal of Accountancy, 193(1), 63.

Husted, K., \& Michailova, S. (2004). Decision making in organizations hostile to knowledge sharing. Journal for East European Management Studies, 9(1), 7-19.

Huysman, M. (2001). Balancing biases: A critical review of the literature on organizational learning. In Easterby-Smith, M., Burgoyne, J., \& Araujo, L. (Eds.), Organizational Learning and the Learning Organization: Developments in Theory and Practice (pp. 59-74). London: Sage.

Imber, M., \& Neidt, W. (1990). Teacher participation in school decision making. In: R. Reyes (Ed.) Teachers and their Workplace: Commitment, Performance, and Productivity (pp. 67-85). Newbury Park, C. A.: Sage.

Institute of Certified Public Accountants of Singapore. (2005). Press release. Revised statement of recommended accounting practice 6: Accounting and reporting by charities (RAP 6). Retrieved from http://www.icpas.org.sg/doc/press/ED_RAP_6_comments.htm

Jackson, S. E., Hitt, M. H., \& DeNisi, A. (2003). Managing knowledge for sustained competitive advantage. New York, N.Y.: John Wiley and Co.

Jain, S. (1984). Environmental scanning in US corporations. Long Range Planning, 17(2), 117-128. http://dx.doi.org/10.1016/0024-6301(84)90143-2

Jansen, P. (2004). Performance measurement in government organization: A contingent approach to measurement and management control. Managerial Finance, 30(8), 54-68. http://dx.doi.org/10.1108/03074350410769227

Jarzabkowski, P. (2005). Strategy as practice: An activity-based approach. London: Sage.

Jensen, J. A., \& Rasmussen, O. E. (2004). An inquiry into the foundations of organizational learning and the learning organization. The Learning Organization: An International Journal, 11(6), 478-490. http://dx.doi.org/10.1108/09696470410548836

John, D. P. (2003). The connection between trust and knowledge management: What are its implications for team $\begin{array}{lll}\text { performance? Journal of Knowledge } & \text { Management, }\end{array}$ http://dx.doi.org/10.1108/13673270310505386

Jones, R., \& George, J. (1998). The evolution of trust and cooperation: Implication for teamwork and tacit knowledge. Academy of Management Review, 23(2), 531-546.

Joyce, P. G. (1999). Performance-based budgeting. In R.T. Meyers (Ed.) Handbook of Government Budgeting. (pp. 597-619). San Francisco: Jossey-Bass Publishers.

Kanter, R., \& Summers, D. (1987). Doing well while doing good: Dilemmas of performance measurement. In non-profit organizations and the need for a multiple-constituency approach. In Powell, W.W. (Ed.) The Non-profit Sector: A Research Handbook. London: Yale University Press.

Kaplan, R. S. (2001). Strategic performance measurement and management in non-profit organizations. Non-Profit Management and Leadership, 11, 353-370. http://dx.doi.org/10.1002/nml.11308 
Kettner, P., Moroney, R., \& Martin, L. (1996). Designing and Managing Programmes: Effectiveness - Based Approach. Newbury Park, C.A.: Sage Publications.

Keyton, J. (2005). Communication and organizational culture. Thousand Oaks, C.A.: Sage.

Kim, D. H. (1993). The link between individual and organizational learning. Sloan Management Review, 35(1), $37-50$.

Lam, A. (2000). Tacit knowledge, organizational learning and societal institutions: An integrated framework. Organization Studies, 21(3), 487-513. http://dx.doi.org/10.1177/0170840600213001

Levin, D., \& Cross, R. (2004). The strength of weak ties you can trust: The mediating role of trust in effective knowledge transfer. Management Science, 50, 1477-1490. http://dx.doi.org/10.1287/mnsc. 1030.0136

Lewis, M., \& Moultrie, J. (2005). The organizational innovation laboratory. Creativity and Innovation Management, 14(1), 73-83. http://dx.doi.org/10.1111/j.1467-8691.2005.00327.x

Light, P. (2000). Making non-profit work: A report on the tides of non-profit management reform. Washington, D.C.: Brookings Institute.

Linda, S. W. (2005). Leadership in high-performance teams: A model for superior team performance. Team Performance Management, 11(1/2), 4-11. http://dx.doi.org/10.1108/13527590510584285

Lipsky, M., \& Smith, S. (1990). Non-profit organizations, government, and the welfare state. Political Science Quarterly, 104, 625-648. http://dx.doi.org/10.2307/2151102

Lopez, P. S., Pean, M. J. M., \& Ordas, V. C. J. (2005). Organizational learning as a determining factors in business performance. The Learning Organization: An International Journal, 12(3), 227-245. http://dx.doi.org/10.1108/09696470510592494

Lyons, M. (2001). Third sector: The contribution of non-profit and co-operative enterprises in Australia. St Leonards: Allen and Unwin.

Lynn, Eakin, Matthew, Kealey., \& Katherine Van K. (2006). Taking stock: Examining the financing of non-profit community organizations in Calgary.

Marwick, A. D. (2001). Knowledge management technology. IBM Systems Journal on Knowledge Management. New York, N.Y.: IBM Press, Armonk.

Mattessich, P. W. (2003). The manager's guide to programmed evaluation: Planning, contracting, and managing for useful results. St. Paul, M.N.: Wilder Publishing Center.

McDougall, M., \& Beattie, R. S. (1998). The missing link? Understanding the relationship between individual and organizational learning. International Journal of Training and Development, 2(4), 288-299. http://dx.doi.org/10.1111/1468-2419.00055

McEvily, B., Perrone, V., \& Zaheer, A. (2003). Trust as an organizing principle. Organization Science, 14(1), 91-103. http://dx.doi.org/10.1287/orsc.14.1.91.12814

Michael, G. (2002). Protecting volunteers and non-profit organizations: A study on risk management and liability insurance of voluntary organization in British Columbia. United Community Services Co-op Volunteer BC.

Ministry of Trade and Industry. (2007). Singapore Economy. Retrieved from http://app.mti.gov.sg/default.asp?id=1

Mintzberg, H., Ahlstrand, B., \& Lampel, J. (1998). Strategy safari. Hemel Hempstead, Hertfordshire: Prentice Hall.

Mirghani, M., Michael, S., \& Arthur, M. (2004). Applying knowledge management principle to enhance cross-functional team performance. Journal of Knowledge Management, 8(3), 127-142. http://dx.doi.org/10.1108/13673270410541097

Molinari, C., Morlock, L., Alexander, J., \& Lyles, C. A. (1992). Hospital board effectiveness: Relationships between board training and hospital financial viability. Health Care management Review, 17, 43-49.

Moilanen, R. (2005). Diagnosing and measuring learning organizations. The Learning Organization, 12(1), 71-89. http://dx.doi.org/10.1108/09696470510574278

Morley, E., Hatry, H., \& Cowan, J. (2002). Making use of outcome information for improving services: Recommendations for non-profit organizations. Washington, D.C: Urban Institute. 
Murray, P., \& Moses, M. (2005). The centrality of teams in the organizational learning process. Management Decision, 43(9), 1186-1202. http://dx.doi.org/10.1108/00251740510626263

Natalie, B. (1999). Associations between outcome measurement, accountability and learning for non-profit organizations. The International Journal of Public Sector Management, 12(2), 186-197. http://dx.doi.org/10.1108/09513559910263499

Nathan, M. L. (1998). The non-profit executives as chief learning officer. Non-profit World, 16(2), 39-41.

National Council of Social Services. (2004/2005/2007). Annual report. Retrieved from http://www.ncss.org.sg/ncss/about_ncss/annual_report.html

National Council of Social Services. (2008). Funding for VWOs: NCSS funding principles. Retrieved from http://www.ncss.org.sg/vwocorner/funding.asp

National Council of Social Services. (2009). Funds disbursement and allocation. Retrieved from http://www.ncss.org.sg/documents/0708fund_DA.pdf

National Volunteers and Philanthropy Centre. (2004). Online Publication. Retrieved from http://www.nvpc.org.sg/npo/

Oliver, S., \& Kandadi, K. R. (2006). How to develop knowledge culture in organizations? A multiple case study of large distributed organizations. Journal of Knowledge Management, 10(4), 6-24. http://dx.doi.org/10.1108/13673270610679336

Ortenbald, A. (2001). On differences between organizational learning and learning organization. Learning Organization, 8(3/4), 125-133. http://dx.doi.org/10.1108/09696470110391211

Osterloh, M., \& Frey, B. (2000). Motivation, knowledge transfer, and organizational forms. Organization Science, 11(5), 538-550. http://dx.doi.org/10.1287/orsc.11.5.538.15204

Pappas, A. T. (1996). Reengineering your non-profit organization: A guide to strategic transformation. New York: John Wiley and Sons. Inc.

Parsons, L. (2003). Is accounting information from non-profit organization useful to donors? A review of charitable giving and value-relevance. Journal of Accounting Literature, 22, 104.

Paton, R., \& Foot, J. (1997). Dashboards for non-profits - A new approach to an old problem? Paper presented at the 1997 meeting of the Association for Research on Non-profit Organizations and Voluntary Action, Indianapolis.

Pearce, J. A., \& David, F. (1987). Corporate mission statements: The bottom line. Academy of Management Executive, 1(2), 109-116. http://dx.doi.org/10.5465/AME.1987.4275821

Petra C. de Weerd-N., Bernice J. P., Jorge F. da Silva G., \& Alan W. P. (2002). Tools for the improvement of organizational learning processes in innovation. Journal of Workplace Learning, 14(8), 320-331. http://dx.doi.org/10.1108/13665620210449164

Pfeffer, J. (1982). Organizations and organization theory. Boston: Pittman.

Pharoah, C. (2008). Charity market monitor, Volume one: Fundraisers. Caritas data and Cass Business School.

Plantz, M., Greenway, M., \& Hendricks, M. (1997). Outcome measurement: Showing results in the non-profit sector. In K. E. Newcomer (Ed.) New Directions for Evaluation. (pp. 15-30). San Francisco: Jossey-Bass Publishers.

Popper, M., \& Lipshitz, R. (2000). Organizational learning: Mechanisms, culture, and feasibility. Management Learning, 31(2), 181-201. http://dx.doi.org/10.1177/1350507600312003

Posavac, E. J., \& Carey, R. (2002). Programme evaluation: Methods and case studies. Englewood Cliffs, N.J.: Prentice Hall.

Prahald, C. K., \& Bettis, R. A. (1986). The dominant logic: A new linkage between diversity and performance. Strategic Management Journal, 7(6), 485-502. http://dx.doi.org/10.1002/smj.4250070602

Probst, J. B., \& Buchel, B. (1997). Organizational learning: The competitive advantage of the future. London: Simon and Schuster.

Rhodes, J., Peter, L., Richard, H., \& Fang, S. C. (2008). An integrative model of organizational learning and social capital on effective knowledge transfer and perceived organizational performance. Journal of Workplace Learning, 20(4), 245-258. http://dx.doi.org/10.1108/13665620810871105 
Robert, Roach (2006). The non-profit and voluntary sector in Alberta: Regional highlights from the national survey of non-profit and voluntary organizations.

Robson, P. J. A., \& Tourish, D. (2005). Managing internal communication: An organizational case study. Corporate Communication, 10(3), 213-222. http://dx.doi.org/10.1108/13563280510614474

Rodrik. (2005). Growth Strategies. In P. Aghion and S. Durlauf (Ed.) Handbook of Economic Development.

Roland, Y. (2002). From individual to team learning: Practical perspectives on the learning organization. Team Performance Management, 7(8), 157-170.

Rose, A. S. (1996). Altruism, nonprofits, and economic theory. Journal of Economic Literature, 34(2), 701-728.

Rossi, P. H., Lispsey, M., \& Freeman, H. (2004). Evaluation: A systematic approach. Thousand Oaks. C.A.: Sage Publications.

Sabherwal, R., \& Becerra-Fernandez, I. (2003). An empirical study of the effect of knowledge management processes at individual, group, and organizational levels. Decision Sciences, 34(2), 225-260. http://dx.doi.org/10.1111/1540-5915.02329

Sabo, K., \& Fusco, D. (2002). Participatory evaluation for continuous improvement. The Evaluation Exchange: Harvard Family Research Project, 8(2), 12.

Salamon, L. M. (1987). Partners in public service: The scope and theory of government-non-profit relations. In W. W. Powell (Ed.), The Non-Profit Sector: A Research Handbook (pp. 99-117). New Haven, C.T.: Yale University Press.

Sargeant, A., \& Bennett, R. (2004). The non-profit marketing landscape: A brief review of developments in the field. Journal of Business Research, 58(6), 797-805.

Sawhill, J., \& Williamson, D. (2001). Mission impossible? Measuring success in non-profit organizations. Non-Profit Management and Leadership, 11, 371-386. http://dx.doi.org/10.1002/nml.11309

Scarborough, H., \& Swan, J. (2003). Discourses of knowledge management and the learning organization: Their production and consumption. In Easterby-Smith, M., \& Lyles, M. (Eds.), The Blackwell Handbook of Organizational Learning and Knowledge Management (pp. 495-512). Oxford: Blackwell Publishing,

Schein, E. H. (2004). Organizational culture and leadership. San Francisco, C.A.: Jossey-Bass.

Scott, J. T. (1995). Some thoughts on theory development in the voluntary and non-profit sector. Non-Profit Voluntary Sector Quarterly, 24(1), 31-40. http://dx.doi.org/10.1177/089976409502400106

Senge, P. M. (1990a). The fifth discipline: The art and practice of the learning organization. New York: Doubleday.

Senge, P. M., Schein, E. D., S. A., \& Gallwey, G. (1994). The new workplace: Transforming the character and culture of our organizations. M. A.: Pegasus Communications.

Senge, P. M. (1990b). The leader's new work: Building learning organizations. Sloan management review, 32(1), 7-23.

Shim, J., \& Siegel, J. (1997). Financial management for non-Profits. Boston: McGraw-Hill.

Slater, S. F., \& Narver, J. C. (1995). Market orientation and the learning organization. Journal of Marketing, 59, 63-74. http://dx.doi.org/10.2307/1252120

Smith, W. J., Howard, J. T., \& Harrington K. V. (2005). Essential formal mentoring characteristics and functions in governmental and non-governmental organizations from the program administrator's and mentor's perspective. Public Personnel Management, 34(1), 1-28.

Smith, E. A. (2001). The role of tacit and explicit knowledge in the workplace. Journal of Knowledge Management, 5(4), 311-321. http://dx.doi.org/10.1108/13673270110411733

Sosik, J. J., \& Lee, D. L. (2002). Mentoring in organizations: A social judgment perspective for developing tomorrow's leaders. The Journal of Leadership Studies, 8, 17-32. http://dx.doi.org/10.1177/107179190200800402

Speckbacher, G. (2003). The economics of performance management in non-profit organizations. Non-Profit Management and Leadership, 13(3), 267-281. http://dx.doi.org/10.1002/nml.15

Stevenson, J. F., Florin, P., Mills, D. S., \& Sanrade, M. (2002). Building evaluation capability in human service organizations: A case study. Evaluation and Programme Planning, 25, 233-243. 
http://dx.doi.org/10.1016/S0149-7189(02)00018-6

Stone, M. Bigelow, B., \& Crittenden, W. (1999). Research on strategic management in non-profit organization. Administration and Society, 31, 378-424. http://dx.doi.org/10.1177/00953999922019184

Sun, P. Y. T., \& Scott, J. L. (2003). Exploring the divide-organizational learning and learning organization. The learning organization, 10(4), 202-215. http://dx.doi.org/10.1108/09696470310476972

Susana, P. L., Jose, M. M., \& Camilo, J. V. (2005). Organizational learning as a determining factor in business performance. The Learning Organization, 12(3), 227-245. http://dx.doi.org/10.1108/09696470510592494

Thomas, K., \& Allen, S. (2006). The learning organization: A meta-analysis of themes in literature. The Learning Organization, 13, 123-139. http://dx.doi.org/10.1108/09696470610645467

Tinkelman, D. (1999). Factors affecting the relation between donations to non-profit organizations and an efficiency ratio. Research in Government and Non-profit Accounting, 10, 135-161.

Tsang, E. W. K. (1997). Organizational learning and the learning organization: A dichotomy between descriptive and prescriptive research. Human Relations, 50(1), 73-89. http://dx.doi.org/10.1177/001872679705000104

Vazquez, R., Avarez, L., \& Santos, M. (2002). Market orientation and social services in private non-profit $\begin{array}{lllll}\text { organizations. European Journal of Marketing, 36(9/10), 1022-1046. } & \text {. }\end{array}$ http://dx.doi.org/10.1108/03090560210437316

Vera, D., \& Crossan, M. (2005). Improvisation and innovation performance in teams. Organizational Science, 16(3), 203-224. http://dx.doi.org/10.1287/orsc.1050.0126

Watkins, K. E., \& Marsick, V. J. (1997). In action: Creating the learning organization. Virginia: American Society for Training and Development.

Watkins, K. E., Marsick, V. J., \& Phillips, J. J. (1996). Creating the learning organization. Alexandria, V.A.: American Society for Training and Development.

Watkins, K., Yang, B., \& Marsick, V. (2004). The Construct of Learning Organization: Dimensions, Measurement and Validation. Human Resource Development Quarterly, 15(1), 31-55. http://dx.doi.org/10.1002/hrdq.1086

Watson, T. (2005). Organizations, strategies and human resoucing. In J. Leopold, L. Harris, and T. Watson (Eds.), The strategic managing of human resource (pp. 7-33). Prentice Hall.

Weisbrod, B., \& Dominguez, N. (1986). Demand for collective goods in private non-profit markets: Can fund-raising expenditures help overcome free-rider behaviour? Journal of Public Economics, 30, 83-95. http://dx.doi.org/10.1016/0047-2727(86)90078-2

Werther, W., \& Berman, E. (2001). Third sector government: The art of managing non-profit organizations. Washington, D. C.: Georgetown University Press.

Whittington, R. (2003). The work of strategizing and organizing: For a practice perspective. strategic organization, 1, 117-125.

Wilhelm, V., \& I, Fiestas. (2005). Exploring the link between public spending and poverty reduction: Lessons from the 1990s. Washington, D. C.: World Bank Institute.

Wong, K. Y., \& Aspinall, E. (2003). Is knowledge management equivalent to information technology? Proceedings of the 4th European Conference on Knowledge Management (pp. 989-997). Oxford: Oxford University.

Woodbury, T. J. (2006). Building organizational culture - Word by word. Leader to Leader, 2006(39), 48-54. http://dx.doi.org/10.1002/ltl.165

Yang, Jen-te. (2007). The impact of knowledge sharing on organizational learning and effectiveness. Journal of Knowledge Management, 11(2), 83-90.

Yang, B., Watkins, K., \& Marsick, V. (2004). The Construct of Learning Organization: Dimensions, Measurement and Validation. Human Resource Development Quarterly, 15(1), 31-55. http://dx.doi.org/10.1002/hrdq.1086

Yeo, R. K. (2005). Revisiting the roots of learning organization: A synthesis of the learning organization literature. The Learning Organization, 12, 368-382. http://dx.doi.org/10.1108/09696470510599145

Yoder, D, E., \& Ferris, J. M. (1997). Making sense of performance measurement in the non-profit sector. 
Alexandria, V.A: Paper prepared for the Independent Sector Spring Research Forum.

Young, D. R. (1993). Emerging themes in non-profit leadership and management. In D.R. Young, R. M Hollister, V. A. Hodgkinson, and Associates (Eds.), Governing, Leading, and Managing Non-Profit Organizations (pp. 1-13). San Francisco: Jossey-Bass.

Zahra, S. A., \& George, G. (2002). Absorptive capacity: A review, re-conceptualization, and extension. Academy of Management Review, 27(2), 185-203. 